\title{
Small heat shock proteins in neurodegenerative diseases
}

\author{
Leen Vendredy ${ }^{* 1}$ • Elias Adriaenssens ${ }^{* 1} \cdot$ Vincent Timmerman $^{1}$
}

Accepted: 12 March 2020 / Published online: 22 April 2020

(C) The Author(s) 2020

\begin{abstract}
Small heat shock proteins are ubiquitously expressed chaperones, yet mutations in some of them cause tissue-specific diseases. Here, we will discuss how small heat shock proteins give rise to neurodegenerative disorders themselves while we will also highlight how these proteins can fulfil protective functions in neurodegenerative disorders caused by protein aggregation. The first half of this paper will be focused on how mutations in HSPB1, HSPB3, and HSPB8 are linked to inherited peripheral neuropathies like Charcot-Marie-Tooth (CMT) disease and distal hereditary motor neuropathy (dHMN). The second part of the paper will discuss how small heat shock proteins are linked to neurodegenerative disorders like Alzheimer's, Parkinson's, and Huntington's disease.
\end{abstract}

Keywords Small heat shock proteins - Hereditary peripheral neuropathies - Diseases of the central nervous system . Neurodegeneration $\cdot$ Protein aggregation

\section{Introduction}

Small heat shock proteins (sHSPs) are molecular chaperones whose canonical function is to preserve cellular proteostasis. Unlike heat shock proteins with an ATPase domain (e.g., HSP70), sHSPs are ATP-independent chaperones that recognize and bind unfolded or misfolded proteins. Target proteins are kept in a folding-competent state until ATP-dependent heat shock proteins complete the refolding process (Haslbeck et al. 2005). When proper folding fails, sHSPs aid in the clearance of these target proteins by routing them to one of the degradation systems. The family comprises 10 members (HSPB1$10)$, which all share a characteristic, conserved $\alpha$-crystallin domain (ACD) flanked by variable $\mathrm{N}$-terminal and $\mathrm{C}$ terminal domains (Table 1). The tissue distribution depends on the individual protein and varies from ubiquitous to tissue specific. A remarkable feature of most sHSPs, which has been considered important for their function, is their ability to form a wide range of oligomers (Haslbeck and Vierling 2015). These oligomers are assembled from dimeric building blocks

* Leen Vendredy and Elias Adriaenssens contributed equally to this work.

Vincent Timmerman

vincent.timmerman@uantwerpen.be

1 Department of Biomedical Sciences and Institute Born Bunge, Peripheral Neuropathy Research Group, University of Antwerp, Antwerp, Belgium that interact with each other and typically range from 12 to greater than 32 subunits. The chaperone activity of most sHSPs has been characterized in vitro (Mymrikov et al. 2017), but there is no consensus yet on the active sHSP species, as chaperone activity has been assigned to large oligomers (Franzmann et al. 2005; Bepperling et al. 2012), small oligomers (Stengel et al. 2010; Fleckenstein et al. 2015), dimers (Van Montfort et al. 2001), and even monomers (Almeida-Souza et al. 2010; Alderson et al. 2019).

Despite their multifunctionality and ubiquitous expression, mutations in HSPB1 and HSPB8 affect specifically the peripheral nervous system causing the axonal form of CharcotMarie-Tooth neuropathy (CMT2) and/or distal hereditary motor neuropathy (dHMN) (Evgrafov et al. 2004; Irobi et al. 2004). Later, through a candidate gene approach, it was reported that also HSPB3 may cause dHMN (Kolb et al. 2010). $\mathrm{dHMN}$ are a group of clinically and genetically heterogeneous diseases characterized by degeneration of motor neurons in the peripheral nervous system. Patients experience progressive motor impairment, weakness, and atrophy of distal limb muscles, suggesting a length-dependent neurodegeneration affecting primarily the longest motor axons. Sensory neurons are usually not involved in dHMN. In contrast, CMT patients present with both motor and sensory symptoms. However, many CMT2 patients present with only minor sensory involvement, making it difficult to distinguish dHMN from CMT2 (Harding and Thomas 1980). Intriguingly, genetic overlap is observed between CMT and dHMN as both 
diseases can be caused by mutations in the same gene and even by the same mutation. Moreover, it was recently demonstrated that some patients with HSPB1 and HSPB8 mutations may have rare forms of ALS or distal myopathy, respectively, further supporting the genetic and clinical heterogeneity (Dierick et al. 2007; Capponi et al. 2016; Ghaoui et al. 2016; Echaniz-Laguna et al. 2017b). To date, no effective treatment is available to delay or cure patients with sHSP mutations. Understanding the molecular mechanisms of sHSPs is essential for the development of new therapies, which represents a big challenge due to the wide variety of functions exerted by these proteins.

While mutations in certain sHSPs give rise to degeneration of the peripheral nervous system, degeneration of the central nervous system may also involve sHSPs. Central nervous system disorders are often caused by mutations in genes other than sHSPs, which render the produced protein more susceptible to aggregation. These protein aggregates are typically one of the hallmarks of these diseases. As sHSPs may recognize and prevent these proteins from aggregating, sHSPs were found to be involved in many neurodegenerative disorders and became interesting targets for protective strategies (Kampinga and Bergink 2016). Typical examples of such protein aggregation diseases are Alzheimer's, Parkinson's, and Huntington's disease.

In this paper, we will first summarize how mutations in HSPB1, HSPB3, and HSPB8 cause hereditary peripheral neuropathies. In addition, as part of their core function, sHSPs prevent and counter other proteins from aggregating. Manipulation of sHSP expression or activity has become an attractive approach to ameliorate neurodegenerative diseases, which we will outline in the second part of this paper.

\section{Mutations in sHSPs causing neurodegenerative diseases}

\section{HSPB1}

Patients with HSPB1 mutations usually present with progressive weakness of the legs, with bilateral foot drop often arising as the first symptom. The age of onset is usually in the second decade of life, although onsets up to the seventh decade of life have also been reported (Harding and Thomas 1980; Capponi et al. 2011; Echaniz-Laguna et al. 2017a; Rossor et al. 2017). Disease progression is slow and a significant percentage of patients develop upper limb weakness over the years, leading to loss of ambulation, resulting eventually in wheelchair dependence. Patients may also suffer from mild sensory involvement, although the degree of involvement is highly variable and can even differ between affected members of the same family (Rossor et al. 2017). Other common features include mildly elevated creatine kinase levels, foot deformities, and thigh and hand weakness; and CNS involvement was observed in $5-10 \%$ of the patients (Echaniz-Laguna et al. 2017a, Rossor et al. 2017). So far, over 30 different mutations have been found in the HSPB1 gene leading to inherited peripheral neuropathies (Fig. 1, Table 2). Depending on the protein domain where the mutations are located, the impact on protein function and the clinical outcome of the patient can

Table 1 Members of the sHSP family and related diseases

\begin{tabular}{|c|c|c|c|}
\hline Name & Expression & Associated disease(s) & Target disease aggregates \\
\hline $\begin{array}{l}\text { HSPB1 } \\
\text { (HSP27) }\end{array}$ & Ubiquitous & $\begin{array}{l}\mathrm{CMT} 2, \mathrm{dHMN} \text {, cancer, ischemia and } \\
\text { reperfusion }\end{array}$ & $\mathrm{A} \beta$, tau, $\alpha$-synuclein, huntingtin, SOD1 \\
\hline $\begin{array}{l}\text { HSPB2 } \\
\quad \text { (MKBP) }\end{array}$ & Heart and skeletal muscle & / & $\mathrm{A} \beta^{\mathrm{a}}$ \\
\hline $\begin{array}{l}\text { HSPB3 } \\
\text { (HSPL27) }\end{array}$ & $\begin{array}{l}\text { Heart, brain, skeletal and smooth } \\
\text { muscle }\end{array}$ & CMT2, dHMN, myopathy & l \\
\hline $\begin{array}{l}\text { HSPB4 } \\
\text { (CRYAA) }\end{array}$ & Eye lens, skeletal muscle & Cataract & l \\
\hline $\begin{array}{l}\text { HSPB5 } \\
\text { (CRYAB) }\end{array}$ & Ubiquitous & $\begin{array}{l}\text { Cataract, (cardio)myopathy, ischemia and } \\
\text { reperfusion }\end{array}$ & $\begin{array}{l}\text { A } \beta \text {, tau, } \alpha \text {-synuclein, Ataxin-3, huntingtin, } \\
\text { SOD1 }\end{array}$ \\
\hline $\begin{array}{l}\text { HSPB6 } \\
\text { (HSP20) }\end{array}$ & Ubiquitous & Cardiomyopathy, ischemia and reperfusion & $\mathrm{A} \beta$, huntingtin \\
\hline $\begin{array}{l}\text { HSPB7 } \\
\quad(\mathrm{cvHSP})\end{array}$ & Heart and skeletal muscle & N.A. & Ataxin-3, huntingtin \\
\hline $\begin{array}{l}\text { HSPB8 } \\
\quad \text { (HSP22) }\end{array}$ & Ubiquitous & CMT2, dHMN, myopathy & $\begin{array}{l}\text { Tau, Ataxin-3, huntingtin, TDP-43, C9orf72, } \\
\text { SOD1 }\end{array}$ \\
\hline $\begin{array}{l}\text { HSPB9 } \\
\text { (CT51) }\end{array}$ & Testis & l & Ataxin-3, huntingtin \\
\hline $\begin{array}{l}\text { HSPB10 } \\
\text { (ODF1) }\end{array}$ & Testis & / & l \\
\hline
\end{tabular}

${ }^{\mathrm{a}}$ This result stems from a double HSPB2/HSPB5 knock-out mouse model 


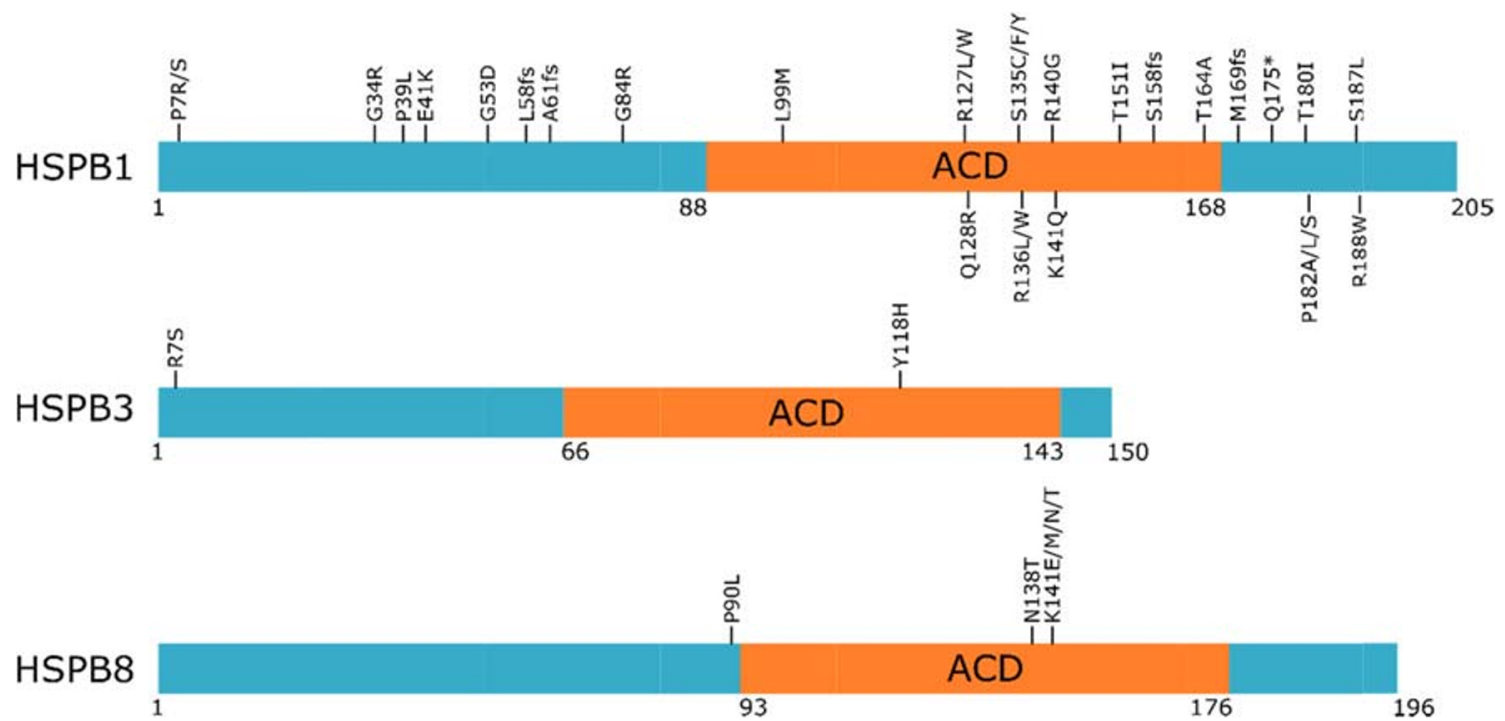

Fig. 1 Overview of all mutations in HSPB1, HSPB3, and HSPB8 reported to cause CMT2/dHMN. *Premature stop codon. fs, frameshift

differ. The majority of the mutations are causative for CMT2/ dHMN and reside in the well-conserved ACD (Nefedova et al. 2015). Inheritance is dominant in most of the patients, but de novo mutations are frequent and rare cases of recessive transmission have been observed. Why mutations in this ubiquitously expressed molecular chaperone lead to almost exclusive neuropathic phenotypes still remains obscure.

To elucidate the pathological mechanisms of HSPB1 mutations, d'Ydewalle et al. (2011) developed and characterized transgenic mice overexpressing human wild-type or mutant HSPB1 (S135F and P182L) using a neuron-specific Thy1.2 promotor. From the age of 6 months onwards, both mutant HSPB1 lines showed a significant reduction of the compound muscle action potential (CMAP) amplitudes and a decreased rotarod performance with progressive worsening over time. The S135F model, but not the P182L, showed sensory abnormalities as assessed by the hot plate test and sensory nerve action potentials (SNAPs). In the presence of mutant HSPB1, $\alpha$-tubulin acetylation was decreased in motor neurons and severe axonal transport deficits were observed in dorsal root ganglion (DRG) sensory neuron explants. Interestingly, using lentiviraltransduced primary motor neurons, it was confirmed that these mitochondrial transport defects also occur in motor neurons. Strikingly, this same study demonstrated that only the retrograde transport of mitochondria (but not other cargo) was affected (Kalmar et al. 2017). This suggests that mitochondrial deficits may be a very specific and important factor in the pathogenesis. Administration of histone deacetylase 6 (HDAC6) inhibitors resulted in an increase of $\alpha$-tubulin acetylation and restored the axonal transport defects in vivo. The restoration of the acetylated $\alpha$-tubulin and accompanied axonal transport led to an improvement of the neuromuscular phenotype (d'Ydewalle et al. 2011). However, despite restoration of the axonal transport defects back to wild type, the motor performance and electrophysiological parameters of these animals were only partially restored. This implies that, besides $\alpha$-tubulin acetylation and axonal transport, additional pathways might contribute to the disease. This is not surprising given the pleiotropic functions HSPB1 fulfils but it offers a window for additional therapies to improve the phenotype further. Interestingly, Regenacy Pharmaceuticals and the Charcot-Marie-Tooth Association teamed up in 2018 to further develop the therapy with ricolinostat (a selective HDAC6 inhibitor) and evaluate its potential for the clinic. So exciting times are ahead with potentially the first treatment for HSPB1 in clinical trial soon.

Some of the first observations made for HSPB1 mutants highlighted important aspects of the underlying molecular biology. Like other sHSPs, HSPB1 can form a wide range of oligomers which are composed of monomers and dimers that dynamically exchange between oligomers (Baldwin et al. 2011). However, some HSPB1 ACD mutants (e.g., R127W, $\mathrm{S} 135 \mathrm{~F}$, and R136W) were shown to reside more in the monomeric state than the wild-type protein. Moreover, these same mutants were found to have a higher chaperone activity (Almeida-Souza et al. 2010). Conversely, disease-causing mutants that did not influence monomerization showed either no change (T151I) or a decrease (P182L/S) in activity (AlmeidaSouza et al. 2010; Almeida-Souza et al. 2011; Chalova et al. 2014). Based on these results, it was proposed that the monomer could be an active form of HSPB1 while other studies suggested that its chaperone activity remains with the dimer (Jovcevski et al. 2015). It has long remained enigmatic whether the monomeric form of HSPB1 truly contributes to its chaperone function. Monomer formation requires reduction of the cysteine residue that otherwise forms an inter-dimer disulphide bond. Now, Alderson et al. (2019) show that the dissociation of HSPB1 into the monomeric state under reducing conditions is accompanied by increased chaperone activity 
Table 2 Mutations reported in HSPB1, HSPB3, and HSB8 involved in hereditary neuropathies (adapted from Adriaenssens et al. 2017)

\begin{tabular}{|c|c|c|c|c|c|c|}
\hline Gene & Disease & Mutation & $\begin{array}{l}\text { Type of } \\
\text { mutation }\end{array}$ & Domain & $\begin{array}{l}\text { Patients, } \\
n^{\text {a }}\end{array}$ & Reference \\
\hline \multirow[t]{31}{*}{ HSPB1 } & \multirow[t]{31}{*}{ CMT2/dHMN } & P7S & Missense & N-Terminal & 1 & Echaniz-Laguna et al. (2017a) \\
\hline & & $\mathrm{P} 7 \mathrm{R}$ & Missense & N-Terminal & 2 & Fortunato et al. (2017) \\
\hline & & G34R & Missense & N-Terminal & 11 & Capponi et al. (2011) \\
\hline & & P39L & Missense & N-Terminal & 10 & $\begin{array}{l}\text { Houlden et al. (2008), Capponi et al. (2011), Echaniz-Laguna } \\
\text { et al. (2017a) }\end{array}$ \\
\hline & & $\mathrm{E} 41 \mathrm{~K}$ & Missense & N-Terminal & 2 & Capponi et al. (2011) \\
\hline & & G53D & $\begin{array}{l}\text { Missense } \\
\quad \text { (recessive) }\end{array}$ & N-Terminal & 1 & Echaniz-Laguna et al. (2017a) \\
\hline & & L58fs*105 & Frameshift & N-Terminal & 1 & Echaniz-Laguna et al. (2017a) \\
\hline & & A61fs*100 & Frameshift & N-Terminal & 1 & Echaniz-Laguna et al. (2017a) \\
\hline & & G84R & Missense & N-Terminal & 3 & Houlden et al. (2008), James et al. (2008) \\
\hline & & L99M & $\begin{array}{l}\text { Missense } \\
\quad \text { (recessive) }\end{array}$ & Alpha-crystallin & 1 & Houlden et al. (2008) \\
\hline & & $\mathrm{R} 127 \mathrm{~W}$ & Missense & Alpha-crystallin & 16 & $\begin{array}{l}\text { Evgrafov et al. (2004), Tang et al. (2005), Dierick et al. (2008), } \\
\text { Echaniz-Laguna et al. (2017a) }\end{array}$ \\
\hline & & $\mathrm{R} 127 \mathrm{~L}$ & Missense & Alpha-crystallin & 3 & Ylikallio et al. (2015) \\
\hline & & Q128R & Missense & Alpha-crystallin & 1 & Echaniz-Laguna et al. (2017a) \\
\hline & & S135F & Missense & Alpha-crystallin & 40 & $\begin{array}{l}\text { Evgrafov et al. (2004), Chung et al. (2008), Houlden et al. (2008), } \\
\text { Echaniz-Laguna et al. (2017a) }\end{array}$ \\
\hline & & $\mathrm{S} 135 \mathrm{C}$ & Missense & Alpha-crystallin & 6 & Benedetti et al. (2010), Oberstadt et al. (2016) \\
\hline & & S135Y & Missense & Alpha-crystallin & 10 & Ylikallio et al. (2014), Rossor et al. (2017) \\
\hline & & R136W & Missense & Alpha-crystallin & 1 & Evgrafov et al. (2004) \\
\hline & & $\mathrm{R} 136 \mathrm{~L}$ & Missense & Alpha-crystallin & 10 & Capponi et al. (2011), Gaeta et al. (2012), Stancanelli et al. (2015) \\
\hline & & R140G & Missense & Alpha-crystallin & 8 & Houlden et al. (2008), Rossor et al. (2017) \\
\hline & & K141Q & Missense & Alpha-crystallin & 4 & Ikeda et al. (2009), Maeda et al. (2014) \\
\hline & & T151I & Missense & Alpha-crystallin & 6 & $\begin{array}{l}\text { Evgrafov et al. (2004), Dierick et al. (2008), (Echaniz-Laguna } \\
\text { et al. 2017a) }\end{array}$ \\
\hline & & $\mathrm{S} 158 \mathrm{fs} * 200$ & Frameshift & Alpha-crystallin & 4 & Mandich et al. (2010), Capponi et al. (2011) \\
\hline & & T164A & Missense & Alpha-crystallin & 3 & Lin et al. (2011) \\
\hline & & M169fs*2 & Frameshift & C-Terminal & 1 & Ylikallio et al. (2015) \\
\hline & & Q175* & Nonsense & C-Terminal & 17 & Rossor et al. (2012), Echaniz-Laguna et al. (2017a) \\
\hline & & T180I & Missense & $\begin{array}{l}\text { C-Terminal } \\
\text { (IXI/V motif) }\end{array}$ & 5 & $\begin{array}{l}\text { Luigetti et al. (2010), Capponi et al. (2011), Echaniz-Laguna } \\
\text { et al. (2017a) }\end{array}$ \\
\hline & & $\mathrm{P} 182 \mathrm{~A}$ & Missense & $\begin{array}{l}\text { C-Terminal } \\
\text { (IXI/V motif) }\end{array}$ & 11 & Rossor et al. (2017) \\
\hline & & $\mathrm{P} 182 \mathrm{~L}$ & Missense & $\begin{array}{l}\text { C-Terminal } \\
\text { (IXI/V motif) }\end{array}$ & 2 & Evgrafov et al. (2004), Dierick et al. (2008) \\
\hline & & $\mathrm{P} 182 \mathrm{~S}$ & Missense & $\begin{array}{l}\text { C-Terminal } \\
\text { (IXI/V motif) }\end{array}$ & 1 & Kijima et al. (2005) \\
\hline & & S187L & Missense & $\begin{array}{l}\text { C-Terminal } \\
\text { (IXI/V motif) }\end{array}$ & 1 & Echaniz-Laguna et al. (2017a) \\
\hline & & R188W & Missense & $\begin{array}{l}\text { C-Terminal } \\
\text { (IXI/V motif) }\end{array}$ & 1 & Capponi et al. (2011) \\
\hline \multirow[t]{2}{*}{ HSPB3 } & \multirow[t]{2}{*}{ CMT2/dHMN } & $\mathrm{R} 7 \mathrm{~S}$ & Missense & N-Terminal & 2 & Kolb et al. (2010), Lassuthova et al. (2016) \\
\hline & & Y118H & Missense & Alpha-crystallin & 2 & Nam et al. (2018) \\
\hline \multirow[t]{4}{*}{ HSPB8 } & \multirow[t]{4}{*}{$\mathrm{CMT} 2 / \mathrm{dHMN}$} & P90L & Missense & N-Terminal & 1 & Echaniz-Laguna et al. (2017a) \\
\hline & & N138T & Missense & Alpha-crystallin & 3 & Echaniz-Laguna et al. (2017a) \\
\hline & & K141N & Missense & Alpha-crystallin & 47 & $\begin{array}{l}\text { Irobi et al. (2004), Tang et al. (2005), Dierick et al. (2008), } \\
\text { Echaniz-Laguna et al. (2017a) }\end{array}$ \\
\hline & & $\mathrm{K} 141 \mathrm{M}$ & Missense & Alpha-crystallin & 2 & Echaniz-Laguna et al. (2017a) \\
\hline
\end{tabular}


Table 2 (continued)

\begin{tabular}{llllll}
\hline Gene Disease & Mutation & $\begin{array}{l}\text { Type of } \\
\text { mutation }\end{array}$ & Domain & $\begin{array}{l}\text { Patients, Reference } \\
n^{\text {a }}\end{array}$ & \\
\hline & K141E & Missense & Alpha-crystallin & 4 & Irobi et al. (2004), Dierick et al. (2008) \\
K141T & Missense & Alpha-crystallin & 1 & Nakhro et al. (2013) \\
\hline
\end{tabular}

${ }^{a}$ The number of patients (reported in literature before the date of submission, April 2019) was determined by incorporating all patients which have undergone neurological examination and for whom the mutation was confirmed by genetic testing

and partial unfolding of the ACD. The $\beta$-strands that mediate dimerization become partially unfolded and highly dynamic in the monomer. Interestingly, a number of HSPB1 mutations cluster to this dynamic region of the monomer. This further supports a role for the monomer and highlights the need to generate a comprehensive understanding of its role in order to decipher the molecular basis of CMT and dHMN.

Besides the increased chaperone activity and increased monomerization, these ACD mutants also increased the affinity of HSPB1 for its clients. Whereas the interaction between wildtype HSPB1 and its clients is transient and weak, making it very difficult to capture them with co-immunoprecipitation or NMR, the introduction of these ACD mutants allowed to readily capture and identify the client proteins bound to HSPB1. In doing so, tubulin was identified as one of the main interactors of HSPB1 (Almeida-Souza et al. 2010; Almeida-Souza et al. 2011). We found that HSPB1 binds along the surface of microtubules and has an important role in maintaining them stabile yet dynamic. Furthermore, HSPB1 not only stabilizes already formed microtubules but also assists during non-centrosomal nucleation of microtubules (Almeida-Souza et al. 2013). As a consequence of the increased affinity for tubulin, the ACD mutants bind stronger to microtubules and cause an overstabilization. These molecular insights into the interaction between HSPB1 and tubulin led to the observation of altered tubulin acetylation in vivo, yielding HDAC6 inhibitors as a new candidate therapy for axonal CMT2 caused by HSPB1 mutations (d'Ydewalle et al. 2011).

In an attempt to explain why HSPB1 mutations only affect such a specific cell type, the study of Holmgren et al. (2013) seems of particular interest. Here, it was demonstrated that in lentiviral-transduced SH-SY5Y cells overexpressing wild-type or mutant HSPB1, the transport of neurofilaments is affected. These neurofilament transport defects were suggested to be caused by a decreased interaction between neurofilament and kinesin due to increased phosphorylation of neurofilaments by CDK5. Interestingly, reducing the CDK5 expression with short hairpin RNAs restored neurofilament phosphorylation and its interaction with kinesin. Similarly, using pharmacological inhibition of CDK5 with roscovitine, the axonal transport of neurofilament was restored. Given the tissue-specific expression of neurofilament and the observation that mutations in neurofilament light (NFL) also cause CMT, this inhibition of CDK5 may provide an appealing pharmacological target.
Besides its canonical chaperone function, HSPB1 is involved in numerous cellular processes, such as apoptosis (Charette et al. 2000; Qi et al. 2014), cytoskeleton dynamics (Der Perng and Quinlan 2004; Almeida-Souza et al. 2011; Clarke and Mearow 2013), translation (Cuesta et al. 2000; Geuens et al. 2017), and autophagy (Tang et al. 2011; Matsumoto et al. 2015). Haidar et al. (2019) recently showed that different mutations in HSPB1 (R127W, S135F, and P182L) lead to an impairment of autophagy, a ubiquitous multi-step process which prevents the accumulation of misfolded proteins and damaged organelles in the cytoplasm. The autophagy receptor SQSTM1/p62 (sequestosome-1 or ubiquitin-binding protein p62) was identified as an interactor of wild-type and mutant HSPB1, the latter showing an increased binding affinity for this client. SQSTM1/p62 clusters ubiquitinated proteins in the cytoplasm in small dense round formations (known as p62 bodies), which form a scaffold for the formation of a double-membraned vesicle referred to as the autophagosome (Yang and Klionsky 2010). HSPB1 mutant cells displayed an impairment of autophagosome formation due to a decrease in the formation of p62 bodies, suggesting that HSPB1 fulfils a regulatory role in autophagy through its interaction with SQSTM1/p62. The autophagy deficits were also confirmed in motor neurons differentiated from patient-derived induced pluripotent stem cells (iPSCs), thereby indicating that the impairment of autophagy might be another pathomechanism by which mutations in HSPB1 cause a peripheral neuropathy.

Most of the studies mentioned above focused on ACD mutants for which it is now well established that they increase the affinity for their molecular clients and subsequently disturb the function of those clients. However, in the C-terminus of HSPB1 lies another well-studied mutation. With a disease onset in the first decade of life and a relatively rapid disease progression, the $\mathrm{P} 182 \mathrm{~L}$ mutation is one of the most severe mutations in HSPB1 (Evgrafov et al. 2004). This P182L mutant resides in the conserved IXI/V motif and increases the oligomer size drastically. In cells, this leads to the formation of very large aggregates which become insoluble (Fig. 2) (Ackerley et al. 2006; Chalova et al. 2014). As a consequence of these altered biophysical properties, it was shown that this mutant is more retained to the neuronal cell body. Also neurofilament medium and p150 were found to have an altered 
a
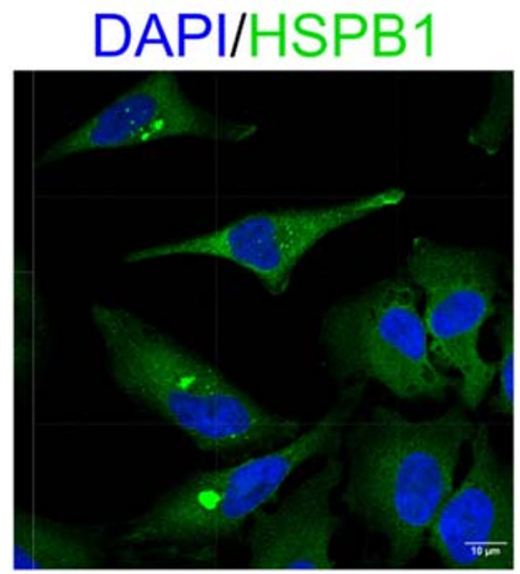

b

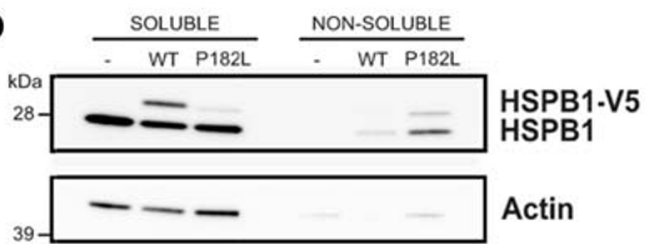

Fig. 2 a Immunocytochemistry of HeLa cells which were lentiviraltransduced with the HSPB1-P182L mutant and decorated with anti-V5 antibodies to visualize HSPB1. Bright green areas are HSPB1 aggregates. b Western blot analysis of the same cells with separation of the NP-40 soluble and insoluble fractions, demonstrating the transition of the HSPB1-P182L from the soluble to the non-soluble fraction. c Immuno-

distribution in primary cortical neurons transduced with HSPB1-P182L (Ackerley et al. 2006). In addition, Geuens et al. (2017) reported the RNA-binding protein named poly $(\mathrm{C})$ binding protein 1 (PCBP1) as a novel interaction partner for HSPB1, to which the P182L bound stronger. As a consequence of this aberrant interaction between HSPB1P182L and PCBP1, there was a loss of translational repression by PCBP1 on its mRNA targets. Surprisingly, a number of CMT-associated genes were among its targets and were found to have an altered expression in a mutant HSPB1-P182L background. Although it is clear that the P182L mutant causes the most severe neuropathy phenotype and obtains certain unique properties due to the mutation (compared with ACD mutants), conclusive data is missing to explain this genotype-phenotype correlation. Based on all the studies mentioned above, it seems that different mutations can impact the affinity of HSPB1 towards different clients, indicating a potential difference in underlying pathomechanism.

In contrast to the $\mathrm{ACD}$ and $\mathrm{C}$-terminus, $\mathrm{N}$-terminal mutations remain under-studied. Interestingly, McDonald et al. (2012) suggested an important role for the N-terminus in binding (at least some) client proteins. Physico-chemical analysis of N-terminal HSPB1 mutants (G34R, P39L, and E41K) in vitro showed an increased stability of large HSPB 1 homooligomers, reduced phosphorylation-dependent dissociation, and a decrease in chaperone capacity, thereby disturbing normal functioning of HSPB1 (Muranova et al. 2015).

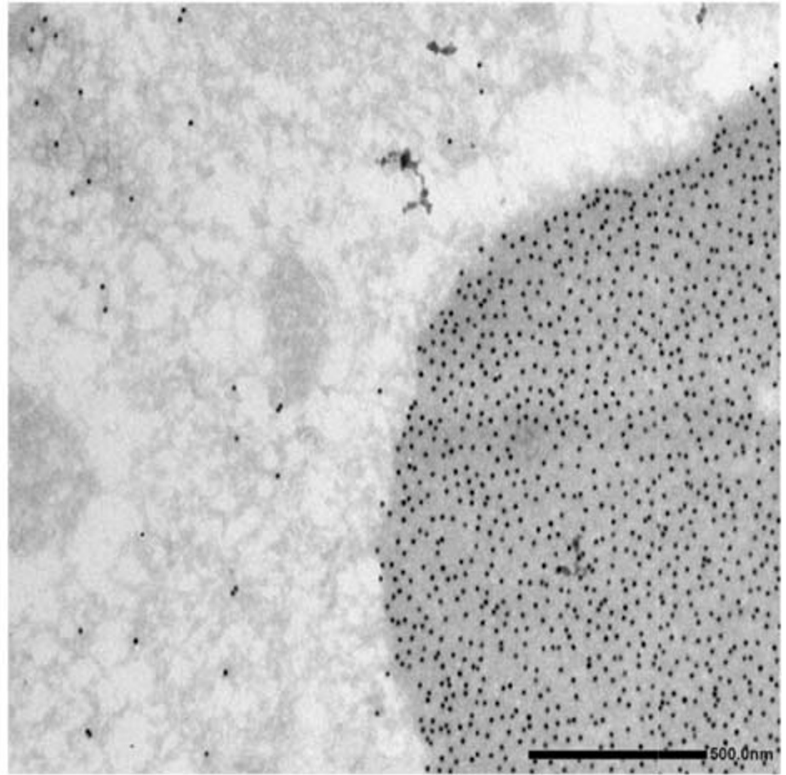

electron microscopy of HeLa cells transduced with GFP-tagged HSPB1 and stained with an anti-GFP antibody. Black dots represent gold-labeled antibodies with the gray and electron-dense GFP-positive HSPB1 protein aggregate on the right, which is located in the cytosol (unpublished results)

Interestingly, although poorly conserved, the N-terminal domain contains a core RLFDQxFG motif present in many members of the sHSP family. Replacement of the arginine (R) by alanine induced spectral changes (absorbance and fluorescence spectrum) and/or changes of temperature-induced aggregation only in the case of HSPB1 and HSPB8, but not for HSPB4, HSPB5, or HSPB6 (Shatov et al. 2018). Finally, one of the few molecular studies on the impact of N-terminal mutants in cells demonstrated that the P39L mutant had a similar effect on mitochondria as the S135F (Kalmar et al. 2017).

In summary, research on HSPB1 mutants has made a lot of progress over the last decade. A number of potential pathomechanisms have been unveiled, such as the impairment of autophagy, altered chaperone activity, the tendency to aggregate, and axonal transport deficits. As many of these results were only obtained in cellulo, it will be critical for future studies to transition these insights into the in vivo situation and to assess for each of these pathways individually whether or not they should be considered contributing factors to the disease.

\section{HSPB3}

In 2010, the first mutation in HSPB3 (R7S) was identified in two siblings diagnosed with dHMN (Kolb et al. 2010). The same mutation was identified later in a Czech patient by a 
gene panel analysis (Lassuthova et al. 2016). A functional follow-up study reported that the R7S mutation had no pathogenic effect upon overexpression in avian motor neurons ( $\mathrm{La}$ Padula et al. 2016). Only recently, a second mutation (Y118H) in HSPB3 was found in two patients presenting with CMT2 symptoms (Nam et al. 2018). Since little is known about the biological function of HSPB3, it is hard to predict the impact of these mutations. In addition, the fact that two large cohort studies on sHSPs did not yield any additional mutations (Capponi et al. 2011; Echaniz-Laguna et al. 2017a) leaves it uncertain whether those HSPB3 variants are truly pathogenic.

Like other sHSPs, HSPB3 is able to form oligomeric structures, which are uniquely composed of hetero-tetramers of HSPB2 and HSPB3 in a 3:1 ratio (Sugiyama et al. 2000; den Engelsman et al. 2009). The R7 residue is close to Nterminal IXI/V motifs that are proposed to bind the $\beta 4 / \beta 8$ pocket of a HSPB2 molecule (Clark et al. 2018). It is therefore suggestible that the replacement of the positively charged arginine by a polar serine affects the ability of the protein to oligomerize and fulfil its biological function. However, data obtained from mass spectrometry and analytical ultracentrifugation of HSPB2/HSPB3-R7S indicated that the mutation has only a minor impact on the hetero-tetramer assembly and stoichiometry (Clark et al. 2018). The Y118 residue lies at the border of the shared groove between HSPB2 and HSPB3, which is important for dimerization. Whether the $\mathrm{Y} 118 \mathrm{H} \mathrm{mu-}$ tation alters the HSPB2-HSPB3 interaction remains to be determined. However, another residue in this groove, R116, is mutated to proline in patients diagnosed with myopathy, which was already shown to disrupt the binding to HSPB2 when assessed by co-immunoprecipitation (Morelli et al. 2017b).

Taken together, as conclusive data is missing on the biological function of HSPB3, it is difficult to predict the consequences of mutations in the HSPB3 gene. Moreover, the fact that only very few families have been identified with an HSPB 3 mutation, and that the pathogenicity of HSPB 3 mutants is not warranted, requires the identification of additional families or patients to firmly establish its causality.

\section{HSPB8}

Patients with HSPB8 mutations present with a very similar phenotype as patients with HSPB1-linked neuropathy, with the exception that thigh weakness, CNS involvement, and autosomal recessive transmission have not been observed. With an estimated prevalence of 5\%, genetic variants in the $H S P B 1$ gene are a frequent cause of CMT2/dHMN, whereas $H S P B 8$ mutations are still rare and account for only $1 \%$ of patients. More recently, the disease spectrum caused by mutations in HSPB8 was expanded to distal myopathy (Ghaoui et al. 2016; Echaniz-Laguna et al. 2017b). Disease-causing variants in HSPB8 predominantly target the same amino acid residue (Lys141) in the highly conserved ACD. This hot-spot residue therefore seems to play an important role in the structure and function of HSPB8. In February 2019, collaborating neurologists Prof. Dr. J. Baets and colleagues performed the first autopsy of a dHMN patient with the HSPB8 K141N mutation (personal communication). The patient was a member of the original Belgian family (Timmerman et al. 1992; Irobi et al. 2004). She passed away at the age of 76 and was wheelchair bound since the age of 48 . The autopsy will allow us to study in detail the neuropathological consequences of this mutation in human and assess its similarities to what has been described for the mouse.

A knock-in mouse model for the $\mathrm{K} 141 \mathrm{~N}$ missense mutation was developed, mimicking the neuropathy phenotype segregating in the originally described Belgian dHMN family (Bouhy et al. 2018; Timmerman et al. 1992). The Hspb8 $8^{K 141 N}$ ${ }^{K 141 N}$ mice showed a progressive and significant reduction of the compound muscle action potential (CMAP) amplitudes from the age of 6 months onwards, which was further supported by a significant decrease in performance on the rotarod. At the molecular level, Hspb8 aggregates were detected by immunohistochemistry in sciatic nerves of 15 months old $H s p b 8^{K 141 N / K 141 N}$ mice but not in $H s p b 8^{+/+}$animals. Additionally, in the muscle of 12-month-old $H s p b 8^{K 141 N /}$ ${ }^{K 141 N}$ mice, we also detected Hspb8-positive aggregates associated with desmin and $\alpha \beta$-crystallin. Interestingly, the $H s p b 8^{-/-}$mice did not develop any motor deficit or electrophysiological abnormalities. Aged $H s p b 8^{--}$mice showed only minor structural irregularities in the muscle which remained subclinical as the mice performed as good as age-matched controls on the rotarod.

The absence of any neuropathological phenotype in the $H s p b 8^{-/}$mice might be explained by (i) the absence of Hspb8 aggregates, (ii) activation of compensatory mechanisms mimicking the role of Hspb8, and (iii) the absence of any additional toxic gain-of-function consequences of the K141N mutant. We have previously shown that mutant human HSPB8 is prone to aggregation in patient fibroblasts (Irobi et al. 2012). However, there is so far no clear consensus on how these aggregates contribute to the neurodegeneration (Adriaenssens et al. 2017; Carra et al. 2019). Regarding the molecular compensation, it is a principle that is frequently observed within the class of the sHSPs (Carra et al. 2019). For instance, multiple sHSPs were shown to bind BAG3 (BCL2-associated athanogene 3; the main binding partner of HSPB8), of which HSPB8 has the highest affinity (Fuchs et al. 2009; Hishiya et al. 2011; Morelli et al. 2017a). It is therefore likely that in the absence of HSPB8, other sHSPs are able to replace HSPB8 and interact with BAG3 to maintain cellular proteostasis. Interestingly, Lys141 mutations were shown to both increase (Echaniz-Laguna et al. 2017a) and decrease (Carra et al. 2010; Shemetov and Gusev 2011) the binding with BAG3. It remains unclear why these studies led to different results, but it is clear that the HSPB8-BAG3 
interaction is directly affected by mutations at this lysine residue. Intriguingly, dominant mutations in the HSPB8-interacting IPV motif of BAG3 are also known to cause myofibrillar myopathy and axonal neuropathy (Selcen et al. 2009; Odgerel et al. 2010; Shy et al. 2018), further implying an important role for this protein complex in neuromuscular homeostasis.

HSPB8 acts as a chaperone in the removal of aggregates through chaperone-assisted selective autophagy (CASA) together with the co-chaperone BAG3, HSP70/HSC70 (heat shock protein/cognate 70), and SQSTM1/p62 (Carra et al. 2008). Client proteins are polyubiquitinated by the E3 ligase STUB1/ CHIP (STIP1 homology and U-box containing protein 1) and subsequently sequestered into cytoplasmic puncta that are labeled with SQSTM1/p62 (also called p62 bodies). SQSTM1/p62 functions as a multi-adaptor protein by binding simultaneously to ubiquitin and the autophagosome-associated protein MAP1LC3/ LC3 (microtubule associated protein 1 light chain 3), allowing misfolded proteins to be inserted into autophagosomes, followed by lysosomal degradation (Ciuffa et al. 2015; Wurzer et al. 2015; Cha-Molstad et al. 2017; Zaffagnini et al. 2018; Turco et al. 2019). Overexpression of wild-type HSPB8 in neuronal cells led to an increased colocalization of autophagosomes with lysosomes while overexpression of mutant HSPB8 (K141N) reduced colocalization between autophagosomes and lysosomes (Kwok et al. 2011). In cells from two dHMN patients with the K141E mutation, a similar impairment of autophagy was observed. Guilbert et al. (2018) reported a role for HSPB8 in ubiquitinated microaggregate formation. Depletion of HSPB8 impaired the formation of these microaggregates and the early formation of p62 bodies. Although they did not include mutant HSPB8 in their experiments, a similar mechanism might explain the autophagic deficits observed in the Hspb $8^{\text {K141N/K141N }}$ mouse model (Bouhy et al. 2018). Interestingly, this is the first time that the two sHSPs, HSPB1 and HSPB8, evidently share the same pathomechanism as their activities merge in SQSTM1/p62 modulation.

The HSPB8-BAG3-HSP70 chaperone complex also helps to maintain the integrity and dynamics of stress granules (Ganassi et al. 2016), which are membrane-less ribonucleoprotein assemblies that form upon proteotoxic stress (Kedersha and Anderson 2002). In contrast to HSPB8, which is immediately recruited into forming stress granules, HSPB1 does not seem to be crucial for the formation of stress granules because neither short hairpin RNA-mediated knockdown nor CRISPR knock-out of HSPB1 affected the formation of stress granules (unpublished data). However, HSPB1 is specifically recruited to aberrant stress granules that contain misfolded proteins, suggesting that it is an important player in their disassembly and thereby protects the cell from toxicity (Mateju et al. 2017). So far, little is known about the influence of neuropathy-linked mutations in HSPB1 and HSPB8 on the formation and dynamism of stress granules. While it is well established that stress granule dysregulation contributes to the motor neuron disease amyotrophic lateral sclerosis (ALS)
(Marrone et al. 2018), it will be an interesting topic to explore further in the context of CMT2/dHMN.

Unrelated to the classical chaperone model, the HSPB8BAG3 complex was reported to be involved in the phosphorylation of eIF $2 \alpha$ (eukaryotic initiation factor 2 alpha) (Carra 2009; Carra et al. 2009) and the remodeling of actin-based mitotic structures (Fuchs et al. 2015). Due to the broad range of functions HSPB8 exerts, it is difficult to pinpoint which functional impairment caused by mutant HSPB8 is responsible for the neuropathic and myopathic disorders.

Until now, most (if not all) studies that attempted to unravel the pathomechanism for HSPB8 were focused on mutants targeting the Lys141 residue. However, missense mutations in HSPB 8 not targeting this Lys141 hot-spot were also reported (Echaniz-Laguna et al. 2017a). Both mutations (P90L and N138T) give rise to an identical motor-predominant phenotype. Surprisingly, none of these mutations changed the affinity of HSPB8 for BAG3. This might suggest that either (i) the protein complex is still intact but that HSPB8 may have become inactive, (ii) the underlying pathomechanism might differ, or (iii) the interaction with BAG3 is not relevant in disease context, although the latter idea seems less appealing at the moment as mutations in BAG3 may also cause CMT2/dHMN (Shy et al. 2018). Moreover, in a recent attempt to identify new interaction partners through immunoprecipitation-mass spectrometry (IPMS), no additional binding partners, apart from BAG3, were found for wild-type or mutant HSPB8 (unpublished results). So further follow-up is required to unambiguously demonstrate the pathogenicity of these non-hot-spot mutations.

In summary, it remains striking how many of the HSPB8 mutations target the same amino acid. Yet, the molecular consequences of these mutations are still poorly understood. For instance, it has been suggested that these mutants lead to protein aggregation of HSPB8. However, it is unknown whether this is driven by HSPB8 itself due to its altered biophysical properties or whether HSPB8 is subjected to an aggregationstimulating environment such as stress granules (a membraneless compartment with a high abundance of hydrophobically exposed residues). These outstanding questions, along with the discovery of yet unknown roles for HSPB8, are topics that will hopefully be enlightened over the following years. In addition, the availability of a mouse model that mimics the patient's phenotype offers the potential to verify in vitro obtained hypotheses and the potential to evaluate candidate therapies for HSPB8 patients.

\section{Small heat shock proteins as modifiers of aggregation-prone neurodegeneration}

Many neurodegenerative disorders are characterized by the accumulation of protein deposits. Such protein deposits are generated through the assembly of insoluble fibrils from 
otherwise soluble proteins. These fibrils can be formed by different proteins, yet they adopt a similar cross- $\beta$ sheet conformation (Eisenberg and Jucker 2012). This process is referred to as amyloidosis and these amyloid structures are among the most stable protein conformations known to date. In some cases, they can even compete with steel in terms of strength (Smith et al. 2006). Amyloid fibrils also occur naturally, and thus not only in disease, as they are known to fulfil biological functions such as pigment formation, neuronal signaling, and hormone release (Fowler et al. 2007; Maji et al. 2009; Roan et al. 2011; Roan et al. 2017; Rice et al. 2019).

Cells thus contain a number of metastable proteins that are more vulnerable for aggregation. In order to prevent these proteins from aggregating, they are subject to tight regulation. However, if this process becomes dysregulated, it may cause fatal neurodegenerative diseases such as Alzheimer's, Parkinson's, and Huntington's disease (Blancas-Mejia and Ramirez-Alvarado 2013; Chuang et al. 2018). Thus, amyloidogenesis does not necessarily require mutations in these metastable proteins to occur. However, mutations in such genes frequently increase their tendency to fibrillize and aggregate. Worryingly, once formed, these amyloid fibrils can self-replicate and transfer between cells; thereby spreading across tissues (Guo and Lee 2014; Goedert et al. 2017).

To control these intrinsic protein instabilities, nature has developed mechanisms to counter uncontrolled protein aggregation (Muchowski and Wacker 2005; Lindberg et al. 2015). However, under certain stressful conditions, these protective systems can be overloaded or become compromised leading to the formation of amyloid-like structures. Below we will discuss some of the most frequent neurodegenerative disorders that are characterized by protein aggregation and highlight the role and potential of sHSPs in controlling the aggregation process.

\section{Alzheimer's disease}

Alzheimer's disease is the most common cause of dementia worldwide and is typically recognized by progressive memory loss and confusion. Pathologically, Alzheimer's disease is characterized by extracellular amyloid plaques (amyloid-beta/A $\beta$ ) and intracellular neurofibrillary tangles (hyperphosphorylated tau) (Selkoe 2001). It is still under debate whether only extracellular $A \beta$ accumulation contributes to the disease or whether also intracellular $A \beta$ pools do (Benilova et al. 2012; Selkoe and Hardy 2016). One view is that amyloid fibrils or their soluble misfolded oligomeric antecedents are directly toxic to cells. This gain-of-function mechanism is supported by the observation that synthetically engineered amyloids or soluble misfolded oligomers with no native function are directly toxic to cells (Bucciantini et al. 2002; Olzscha et al. 2011). However, this does not exclude the possibility that loss-of-function may also contribute to the disease progression as the co-aggregation of other proteins may reduce their availability in the cytosol. Both mechanisms are not necessarily mutually exclusive and may thus contribute to the pathogenesis.

\section{Alzheimer's disease-amyloid-beta/A $\beta$}

The amyloid precursor protein (APP) is a transmembrane protein that is processed by different secretases. However, due to improper cleavage by $\beta$ - and $\gamma$-secretases, neurotoxic $A \beta$ peptides may be formed. These peptides go on to form insoluble amyloid fibrils which accumulate in extracellular senile plaques, a hallmark of Alzheimer's disease.

In Alzheimer patients, both HSPB5 and HSPB8 are upregulated in the brain and found to colocalize with $A \beta$ in senile plaques (Shinohara et al. 1993; Renkawek et al. 1994; Wilhelmus et al. 2006b). HSPB5 was also shown to colocalize with $A \beta$ in the eyes of patients, being the tissue with the highest HSPB5 expression (Goldstein et al. 2003). Similarly, HSPB1 was found to localize to plaques in transgenic mouse models of Alzheimer's disease (Ojha et al. 2011b).

The colocalization of sHSPs with senile plaques could be explained by two mechanisms. Either they fulfil a protective role in these plaques or they were trapped and co-aggregate along with other proteins. To distinguish between these two possibilities (protective versus co-aggregating), cellular and mouse models were employed to study this process in more detail. For instance, neurons cultured from HSPB1-deficient mice were shown to be more sensitive to $A \beta$ oligomermediated toxicity (Ojha et al. 2011b). Similarly, crossing HSPB2/HSPB5 double deficient mice with a transgenic Alzheimer's disease model worsened the phenotype (Ojha et al. 2011a). So, the lack of sHSPs seems to aggravate the Alzheimer's symptoms. In line with this, a transgenic Alzheimer's mouse model subjected to physical activity showed increased expression of HSPB5 accompanying the hippocampal improvements (Huttenrauch et al. 2016). Crossing the APPswe/PS1dE9 mouse model for Alzheimer's disease with a mouse model that overexpresses HSPB1 led to significant improvements in spatial learning and electrophysiological parameters. Moreover, these mice had fewer amyloid plaques in the brain (Toth et al. 2013). These in vivo studies suggest that the lack of sHSPs aggravates the phenotype, whereas an increased expression alleviates the symptoms. This indicates that SHSPs may provide protection.

To understand the underlying principles of this potential protective role, a number of in vitro studies have probed the interaction between sHSPs and A $\beta$. For instance, HSPB1, HSPB5, HSPB6, and HSPB8 were found to inhibit oligomerization of $A \beta$ monomers and prevent oligomers to grow further into fibrils (Wilhelmus et al. 2006a; Wilhelmus et al. 2006b; Dehle et al. 2010; Narayan et al. 2012). Likewise, HSPB4 ( $\alpha$-crystallin) that is naturally only expressed in the 
eye lens was also shown to inhibit fibril formation by $A \beta$ and to counter the $A \beta$-associated cytotoxicity (Santhoshkumar and Sharma 2004). Mechanistically, HSPB5 was suggested to compete with $\mathrm{A} \beta$ monomer-monomer interactions as shown by solution-state NMR spectroscopy (Narayanan et al. 2006). For HSPB6, it was suggested that it provides neuroprotection by binding adjacent to the oligomerization domain of $\mathrm{A} \beta$, preventing its aggregation (Cameron et al. 2014). However, besides countering the initial seeding and formation of $\mathrm{A} \beta$ oligomers, sHSPs were also shown to suppress the elongation phase of already formed amyloid fibrils. This was for instance elegantly demonstrated in a study employing immuno-electron microscopy, which demonstrated that HSPB5 can bind along the entire length of amyloid fibrils (Shammas et al. 2011). This mode-of-action is interesting as it resembles how HSPB1 was shown to bind and stabilize microtubules (Almeida-Souza et al. 2011; Almeida-Souza et al. 2013). In the case of microtubules, this lateral binding was shown to be both sufficient and necessary to maintain the intimate balance between microtubule stability and dynamics. However, in the case of amyloid fibrils, it remains to be studied further how this lateral binding can prevent fibril growth.

\section{Alzheimer's disease-tau}

Another hallmark of Alzheimer's disease, besides the extracellular senile $\mathrm{A} \beta$-plaques, is the formation of intracellular neurofibrillary tangles. These intracellular protein deposits are composed of hyperphosphorylated tau (Caughey and Lansbury 2003). As with many forms of amyloidosis, it is still under debate whether the end stage, neurofibrillary tangles in this case, causes neurodegeneration or whether toxicity is also induced by smaller, soluble tau species, such as tau oligomers (Wang and Mandelkow 2016).

Tau is encoded by the microtubule-associated protein tau (MAPT) gene and causes neurodegenerative diseases referred to as tauopathies (Lee et al. 2001) including some forms of Alzheimer (Ballatore et al. 2007). Tau oligomers have been detected in brain tissues from Alzheimer's patients and their level shows a relation with the degree of memory deficits (Berger et al. 2007).

Both HSPB1 and HSPB5 were shown to colocalize with tau fibrils in tauopathy brains and the amount of HSPB1 and HSPB5 was shown to correlate inversely with the levels of granular tau (Nemes et al. 2004; Sahara et al. 2007; Bjorkdahl et al. 2008). In mice, overexpression of HSPB1 was found to be partially protective against tauopathy (Shimura et al. 2004).

To elucidate the underlying principles, mechanistic in vitro studies demonstrated that HSPB1 can delay tau fibril formation by weakly interacting with early aggregating species. However, this binding is not enhanced under aggregationpromoting conditions suggesting that HSPB1 can delay but not prevent fibril formation (Baughman et al. 2018).
Interestingly, a physical interaction between HSPB1 and tau was confirmed by co-immunoprecipitation and shown to be increased when tau was hyperphosphorylated (Abisambra et al. 2010). This increased affinity of HSPB 1 for hyperphosphorylated tau may actually depend on a small subset of phosphogroups as only certain phosphomimics of tau were found to be slowed down in their aggregation by HSPB1, HSPB5, and HSPB8 (Mok et al. 2018). At the atomic level, very similar models were proposed for HSPB1 and HSPB5 in which competition occurs between the IPV motif of a sHSP and tau for the $\beta 4-\beta 8$ binding site of HSPB1 or HSPB5 (Freilich et al. 2018; Liu et al. 2018). It was noted that increasing concentrations of tau can displace the $\mathrm{C}$-terminal IPV motif and thereby take over the $\beta 4-\beta 8$ binding site in the ACD of HSPB1. However, the ACD binding alone is not sufficient to prevent tau aggregation. The additional contacts with the N-terminus are required, which suggests that the ACD fulfils a role as client sensor while the N-terminus is required for the chaperone function (Freilich et al. 2018).

\section{Parkinson's disease-alpha-synuclein/a-synuclein}

Parkinson's disease is the second most common neurodegenerative disorder after Alzheimer's disease. Clinical diagnosis is often difficult considering the large number of motor and non-motor symptoms patients can present. Parkinson's disease is characterized by neuronal loss in specific areas of the substantia nigra and the widespread aggregation of protein. A major constituent of these intracellular aggregates is $\alpha$-synuclein. Alpha-synuclein is a small $(14 \mathrm{kDa})$ intrinsically disordered protein encoded by the SCNA gene. Neither the loss of dopaminergic neurons in the substantia nigra nor the deposition of $\alpha$-synuclein is specific for Parkinson's disease; however, the combination of both is sufficient to make a definitive diagnosis (Poewe et al. 2017).

There is compelling evidence that $\alpha$-synuclein contributes to both sporadic and familial cases of Parkinson's disease. On the one hand, mutations in SCNA cause early-onset Parkinson's disease due to the production of highly aggregation-prone variants of $\alpha$-synuclein (Trinh and Farrer 2013). On the other hand, mutations in a non-coding distal enhancer element of SCNA result in an increased expression of $\alpha$-synuclein and are considered risk factor for Parkinson's disease (Soldner et al. 2016). So due to genetic mutations, increased abundance, or still unknown factors, $\alpha$-synuclein may transition from soluble monomers to oligomers which further develop into insoluble fibrils.

Multiple sHSPs have been reported to be present in protein aggregates mainly composed of $\alpha$-synuclein, which are also referred to as Lewy bodies (Lowe et al. 1990; Iwaki et al. 1992; Mizutani et al. 1998; McLean et al. 2002; Outeiro et al. 2006; Waudby et al. 2010; Bruinsma et al. 2011; Shammas et al. 2011). sHSPs were shown to counter $\alpha$ - 
synuclein aggregation in vitro and, so far only tested for HSPB5, in vivo (Bruinsma et al. 2011; Duennwald et al. 2012; Prabhu et al. 2012; Tue et al. 2012; Alderson et al. 2019). Moreover, the overexpression of HSPB1 and HSPB5 reduces intracellular aggregation and counters cytotoxicity induced by $\alpha$-synuclein (McLean et al. 2002; Klucken et al. 2004; Zourlidou et al. 2004; Outeiro et al. 2006; Cox and Ecroyd 2017).

The ability of HSPB1 and HSPB5 to inhibit fibril formation was found to be dependent on the rate of aggregation. Faster aggregation (shorter lag phase) led to reduced inhibition by the sHSPs (Cox et al. 2016). Similar to the binding of HSPB5 to A $\beta$ fibrils, HSPB1 was also found to bind along the surface of $\alpha$-synuclein fibrils and thereby decreasing their hydrophobicity (Cox et al. 2018). Interestingly, the HSPB5 interaction domain was mapped to the $\mathrm{N}$-terminus of $\alpha$-synuclein, which is involved in membrane binding (Fusco et al. 2014; Liu et al. 2018). So besides countering $\alpha$-synuclein aggregation, sHSPs may also modulate the way $\alpha$-synuclein induces neurotoxicity.

\section{PolyQ repeat expansion-associated neurodegenerative diseases}

A large group of neurodegenerative diseases is characterized by a DNA repeat expansion. These expanded repeats originate at the genomic level where specific nucleotide repeats challenge the DNA replication machinery which can lead to slippery events and expansion of the repeat sequence. This can occur in both coding and non-coding regions. Surprisingly, both can give rise to protein products which subsequently contain repeats of specific amino acids. The most common repeat expansions code for stretches of glutamine and are therefore referred to as polyQ. The best known example of a non-coding repeat expansion leading to a neurodegenerative disease is found in the C9orf72 gene (this will be discussed under "ALS - C9orf72"). The expansion of repeat regions in the genome may therefore produce protein products which were not necessarily aggregation-prone initially; however, due to the introduction of a long repeat of specific amino acids, it may have acquired novel properties that make them aggregation-prone. Not surprisingly, these peptide repeats can form a significant challenge for chaperone systems as these protein products do not occur naturally. Below we will discuss different polyQ diseases, linked to different neurodegenerative disorders, and highlight where and how sHSPs might be involved in their surveillance.

\section{PolyQ repeat expansion—spinocerebellar ataxia}

Spinocerebellar ataxias are a large group of neurodegenerative disorders of which the most prevalent ones are caused by the expansion of a glutamine-encoding CAG repeat in the respective genes (Paulson et al. 2017). Their inheritance pattern is mostly autosomal dominant and the repeat size is linked to the disease penetrance (Ashizawa et al. 2018). Patients typically present with gait imbalance associated with limb incoordination and problems with gross and fine motor skills.

Through a genome-wide screen in Drosophila for modifiers of Ataxin-3, HSPB5 was identified as modifier for SCA3(78)Q-induced neurodegeneration (Bilen and Bonini 2007). Similarly, the overexpression of Dm-HSP67Bc (the HSPB8 ortholog in Drosophila) and human HSPB8 was found to counter SCA3(78)Q-mediated toxicity in the fly eye while downregulation of Dm-HSP67Bc significantly worsened the phenotype (Carra et al. 2010). In vitro, sideby-side comparison of all sHSPs demonstrated that besides HSPB8, also HSPB7 and HSPB9 are potent chaperones countering polyQ-induced aggregation of Ataxin-3 (Vos et al. 2010).

Mechanistically, HSPB5 was shown to bind to the Josephin domain of Ataxin-3, thereby inhibiting initial aggregation (Masino et al. 2004; Robertson et al. 2010). However, HSPB5 was found inactive against already formed insoluble fibrils of Ataxin-3. In addition to directly binding and modulating the aggregation process, HSPB1 was also shown to counter polyQ-induced cell death by responding to the ROS production (Wyttenbach et al. 2002).

\section{PolyQ repeat expansion-Huntington}

Huntington's disease is an autosomal dominant neurodegenerative disorder characterized by symptoms as chorea and dystonia, the lack of coordination, cognitive decline, and behavioral difficulties. The disease results from a polyQ repeat expansion in the $\mathrm{N}$-terminus of huntingtin. In healthy individuals, this CAG repeat does not exceed 35 copies. However, in individuals with 41 or more copies, it gives rise to the full penetrant neurodegenerative disease (The Huntington's disease collaborative research group, 1993).

Using mutant huntingtin exon-1 as a proxy, it was found that HSPB7 is the most potent sHSP to suppress polyQ aggregation in vitro (Vos et al. 2010). Mechanistically, it was shown that HSPB7 suppresses the formation of new aggregates rather than mediating their degradation (Eenjes et al. 2016). Similarly, HSPB8, its Drosophila ortholog Dm-HSP67Bc, and the human HSPB8-BAG3 protein complex were all shown to have chaperone activity towards polyQ repeats in huntingtin and are capable of reducing the amount of SDSinsoluble huntingtin (Carra et al. 2005; Carra et al. 2009; Carra et al. 2010). Interestingly, while HSPB6, HSPB8, and HSPB9 were most potent against short (43Q) polyQ stretches of huntingtin, HSPB7 was more potent against the longest (119Q) polyQ stretches (Vos et al. 2010). Similar observations were made for mutant androgen receptor (ARpolyQ; causative for spinal and bulbar muscular atrophy) where HSPB8 was 
effective against short polyQ repeats (AR.Q46) but much less against longer AR.Q112 repeats (Carra et al. 2013). In contrast, HSPB1 and HSPB5 seemed to have little effect on polyQ huntingtin aggregation in vitro.

Expression of mutant huntingtin fragments in the lens of mice lacking HSPB5 accelerated the onset and severity of mutant huntingtin aggregation while overexpression of HSPB5 in a transgenic Drosophila model of Huntingon's disease suppressed mutant huntingtin toxicity (Muchowski et al. 2008; Tue et al. 2012). This suggests, in contrast to the in vitro data, that HSPB5 is actually capable of providing protection against Huntington's polyQ aggregation.

Interestingly, mutant huntingtin inhibits HSPB5 expression in astrocytes of the HD140Q mouse model due to a decreased activity of the SP1 transcription factor (Hong et al. 2017). This decrease in HSPB5 was suggested to lead to a reduction of exosome (extra-cellular vesicles) release, a factor that is considered to contribute to the disease pathogenesis. Restoring the HSPB5 expression either through overexpression of SP1 or HSPB5 itself was sufficient to rescue the defective exosome release from astrocytes and showed a clear reduction in mutant huntingtin aggregates (Hong et al. 2017). In line with this, in the exon-1 fragment mouse model R6/2 for Huntington's disease, a downregulation of chaperones including HSPB5 was observed (Zabel et al. 2002; Hay et al. 2004), which was also confirmed in a different mouse model for HTT (BACHD) (Oliveira et al. 2016; Wood et al. 2019). Furthermore, using this same BACHD mouse model for Huntington's disease, overexpression of HSPB5 in astrocytes improved motor performance and cognitive function (Gray et al. 2008; Liu et al. 2015; Oliveira et al. 2016). These improvements in behavioral deficits correlated with mitigation of neuropathological features such as decreased levels of mutant huntingtin and smaller inclusions in BACHD brains. So, overexpression of HSPB5 in astrocytes provides a non-cell autonomous pathway that modulates mutant huntingtin aggregation.

Astrocyte-derived exosomes also contain HSPB1; however, its role in relation to Huntington's disease has provided confusing results (Nafar et al. 2016). On the one hand, a cross of the R6/2 mouse with an HSPB1 overexpression model did not lead to improvement of the R6/2 phenotype (Zourlidou et al. 2007). In contrast, other in vitro and in vivo studies actually did suggest that HSPB1 can be a protective factor for Huntington-associated polyQ repeats (Wyttenbach et al. 2002; Carra et al. 2005; Liao et al. 2008; Chen et al. 2012).

\section{Amyotrophic lateral sclerosis}

Amyotrophic lateral sclerosis (ALS) or Lou Gehrig's disease is a fatal neurodegenerative motor neuron disease. It affects neurons in the brain and spinal cord, leading to muscle weakness, loss of motor functions, paralysis, and breathing problems, eventually leading to death. At the molecular level, ALS is characterized by protein aggregates that accumulate as ubiquitin-positive inclusions in the cytoplasm of degenerating neurons and glia (Hardiman et al. 2017). The far majority of inclusions contain TDP-43 as their main constituent (except for patients carrying mutations in SOD1 or FUS) (van Es et al. 2017). TDP-43 resides primarily in the nucleus where it fulfils a role in transcription. However, when misfolded, it aggregates in the cytosol. These TDP-43 aggregates may be toxic by themselves but may also sequester other essential cellular components. The same might be true for SOD1 or FUS aggregates. Mutations in these three genes cause familial ALS; however, FUS and TDP-43 are of particular interest as they also accumulate in sporadic ALS cases. So their presence might form an important pillar in the pathogenesis; however, the biological processes controlling their formation and/or degradation are still incompletely understood.

\section{ALS-TDP-43 (TARDBP)}

TAR-DNA-binding protein 43 (TDP-43) is a 414-amino acid ribonucleoprotein that resides in the nucleus but shuttles back and forth to the cytoplasm. It is both a DNA- and RNAbinding protein. It regulates transcription either through direct binding to the DNA or by interacting with components of the transcription machinery. In addition, it plays a role in splicing, RNA shuttling, and translation.

Interestingly, the vast majority of all ALS-associated mutations lay in the C-terminal low-complexity prion-like domain (PrLD) (Guo and Shorter 2017). This domain has been suggested to be important for the phase-separating nature of TDP-43; however, it may also form a potential driving site for misfolding and self-templating fibril formation. In the test tube, TDP-43 is very unstable and assembles easily into pore-shaped oligomers and fibrils. These pore-shaped oligomers share similarities with the toxic oligomers formed in other neurodegenerative diseases like $\alpha$-synuclein and $\mathrm{A} \beta$. Addition of these purified oligomers has been shown to cause neurotoxicity both in vitro and in vivo (Lee et al. 2011; Guo and Shorter 2017).

Although TDP-43 is very unstable in the test tube, cells seem to contain protective factors that control this aggregation-prone behavior. One such family of protective factors could be the sHSPs. For example, using a Drosophila model for TDP-43 neurodegeneration, it was shown that overexpression of HSP67Bc (the Drosophila ortholog of HSPB8) rescued the eye degeneration whereas downregulation of HSP67Bc worsened the eye phenotype (Crippa et al. 2016a). TDP-35 and TDP-25 are C-terminal fragments obtained after caspase cleavage of full-length TDP-43. They are frequently used as proxies for rapid induction of protein aggregation. In a Drosophila model overexpressing TDP-35, HSP67Bc rescued pupae lethality (Crippa 
et al. 2016a). Similarly, overexpression of human HSPB8 in neuronal cell models for ALS also protected against aggregation seeding by TDP-25, TDP-35, and TDP-43 (Crippa et al. 2010; Crippa et al. 2016a; Crippa et al. 2016b; Cicardi et al. 2018). Moreover, using an elegant approach, FDA/EMAapproved small molecules that upregulate HSPB8 were identified. Their administration to cellular ALS models greatly reduced the accumulation of misfolded TDP-43 species (Crippa et al. 2016b).

Mechanistically, HSPB8 is thought to team up with other members of the CASA complex to promote autophagosomal degradation of client proteins including TDP-43 species. Surprisingly, inhibition of dynein and thereby the autophagosomal degradation of aggregating substrates by the CASA complex were found to accelerate, instead of halt, the degradation of these client proteins due to a switch to proteasomal degradation (Teuchert et al. 2006; Zhang et al. 2007; El-Kadi et al. 2010; Cristofani et al. 2017).

The potency of other sHSPs for mutant TDP-43 clearance was tested and found, surprisingly, to be very low. So although some of them are very potent towards polyQ substrates, these same chaperones seem not potent against TDP-43 (Carra et al. 2013). This suggests that sHSPs may all have their own specific clients for which they have evolutionary developed chaperone activity.

\section{ALS-C9ORF72}

The most common genetic cause of familial ALS is a massive expansion of the GGGGCC hexanucleotide repeat region in the first intron of C9orf72 (DeJesus-Hernandez et al. 2011; Renton et al. 2011; Gijselinck et al. 2012). This repeat tract is typically between 2 and 30 repeats in healthy individuals, but is increased to hundreds or even thousands in patients (Taylor et al. 2016). Intriguingly, even though this repeat is located in a non-coding region, it is still translated. This nonAUG translation, also called repeat-associated non-AUG (RAN) translation, occurs in both sense (GGGGCC) and antisense (CCCCGG) direction producing five different polymers of the predicted dipeptides, including poly glycinealanine (poly-GA; GGGGCC), poly glycine-proline (polyGP; GGGCCG/GGCCCC), poly glycine-arginine (poly-GR; GGCCGG), poly proline-arginine (poly-PR; CCCCGG), and poly proline-alanine (poly-PA; CCGGCC). The translation of these dipeptide repeats is likely to give rise to metastable structures as they have been shown to form inclusions, both in the cytoplasm and nucleus of neurons from patients (Ash et al. 2013; Mori et al. 2013). Interestingly, these inclusions are negative for TDP-43, even if the patients display a typical TDP-43 pathology (Al-Sarraj et al. 2011; Boxer et al. 2011; Freibaum and Taylor 2017; Vatsavayai et al. 2019).

Given that these dipeptide repeats are not naturally expressed, they may pose a particular challenge to existing chaperones. Which chaperone systems are dealing with these dipeptide repeats has not yet been fully elucidated; however, in vitro results show that overexpression of HSPB8 significantly decreases the accumulation of most dipeptide repeat insoluble species (Cristofani et al. 2018). So the family of sHSPs are putative candidates to deal with these unnatural dipeptides.

\section{ALS-SOD1}

The superoxide dismutase 1 (SOD1) has been linked to both familial and sporadic ALS (Deng et al. 1993; Rosen et al. 1993). For the familial cases, it is thought that SOD1 mutations cause a toxic gain-of-function leading to the disease. A hallmark of these clinical cases is the SOD1-positive inclusions composed of SOD1 protein aggregates.

Both HSPB1 and HSPB8 levels are upregulated in the muscle and/or surviving motor neurons in the spinal cord of transgenic G93A-SOD1 mice, as well as in the spinal cord of ALS patients (Vleminckx et al. 2002; Maatkamp et al. 2004; Krishnan et al. 2008; Anagnostou et al. 2010; Crippa et al. 2010; Crippa et al. 2013).

Molecularly, overexpression of HSPB1, HSPB5, and HSPB8 has been shown to reduce aggregation of SOD1 in vitro (Patel et al. 2005; An et al. 2009; Crippa et al. 2010; Yerbury et al. 2013; Capponi et al. 2016). Interestingly, CMT2/dHMN-associated mutants K141N/E were found to have decreased chaperone activity towards SOD1(G93A). Similarly, overexpression of HSPB1 wild type in astrocytes co-cultured with SOD1(G93A) motor neurons was sufficient to attenuate astrocyte-mediated cytotoxicity. However, CMT2/dHMN-associated mutants of HSPB1 (G84R and $\mathrm{R} 136 \mathrm{~W})$ failed to provide this non-cell-autonomous protective function (Heilman et al. 2017). It requires pointing out though that the R136W mutant was shown to have an overall increased chaperone activity (Almeida-Souza et al. 2010; Almeida-Souza et al. 2011). So loss of this non-cell autonomous protection is unlikely to stem from chaperone failure. Instead, dysregulation of certain pathways due to a toxic gainof-function may provide an explanation.

In vivo, the results are more complicated. Two studies that used a similar setup obtained contradicting results. On the one hand, the crossing of overexpressing HSPB1 mice with SOD1(G93A) mice did not yield neuroprotection, while another lab found that HSPB1 overexpression delays disease progression and increases motor unit survival (Krishnan et al. 2008; Sharp et al. 2008). Additional work is needed to decipher the origin of discrepancy between these two studies.

\section{ALS-FUS}

Mutations in the RNA-binding protein "fused in sarcoma" (FUS) also cause protein aggregation (Neumann et al. 2009; Deng et al. 2010). FUS shows similarities to TDP-43 as it shuttles between the nucleus and the cytosol. In addition, it 
can also bind both DNA and RNA (Deng et al. 2014). FUS undergoes physiological phase separation to form ribonucleoprotein (RNP) granules in the cytoplasm (Boeynaems et al. 2018). However, when FUS is mutated this process can go awry and lead to the formation of insoluble protein aggregates in the cytosol, a hallmark of the disease. Despite the similarities with other ALS-associated genes, such as TDP-43, the link between sHSPs and FUS has not yet been explored. However, given the impact of sHSPs on TDP-43 protein aggregates, it could well be that sHSPs provide protection against FUS aggregation. It will therefore be interesting to see this avenue being explored further.

\section{Conclusions and future perspectives}

In this paper, we summarized the many links between sHSPs and neurodegenerative disorders. For HSPB1 and HSPB8, it is now well substantiated that mutations in both genes cause CMT2 and dHMN. Studying the molecular consequences of these mutations has led to the identification of multiple candidate pathways that could contribute to the disease. However, one important step that should be taken in the next years is the transition to in vivo models. A number of dysfunctional pathways that have been identified in cellular models have not yet been tested in vivo. Given the increasing number of dysfunctional pathways, which is linked to the pleiotropic functions of sHSPs, it has become unclear which of these pathways truly contribute to the pathogenesis. In vivo validation of these candidate pathways will in turn yield novel drug targets which can be tested in these same models. Moreover, the advent of patient-derived induced pluripotent stem cells is likely to become an additional player in the drug development paradigm for CMT2/dHMN (Juneja et al. 2019).

For the neurodegenerative diseases characterized by protein aggregation, the role of sHSPs is only partially understood. A number of sHSPs have been linked to various neurodegenerative disorders; however, the data is not always straightforward to interpret (as they are often obtained from different cellular and animal models). So side-by-side comparisons would aid further in assessing the potency of each of the chaperones individually, although it is to be noted here that the results may also depend on the cell type used to perform these studies. Results should therefore be interpreted with caution when obtained from in vitro models. In vivo models can provide additional information as they not only allow to assess whether a SHSP can reduce the protein aggregation but also allow to assess whether this leads to phenotypic amelioration. Finally, once it is understood which sHSPs are most potent towards which clients, it will become key to identify ways to introduce or upregulate these specific sHSPs in the desired tissues in order to obtain the desired protective effects.
Taken together, although years of research has yielded us much information about the role and link of sHSPs to neurodegeneration, the next years should allow the field to transition more towards in vivo studies and identify potential novel treatment strategies for these neurodegenerative diseases.

Acknowledgments We apologize to all colleagues whose work we could not cover and cite.

Funding information L.V. is supported by a $\mathrm{PhD}$ fellowship of the Flanders Fund for Scientific Research (FWO). E.A. is supported by FWO research grant G041416N and the Rotary "Hope in Head" program. The research on small heat shock proteins is supported in part by grants from the American Muscular Dystrophy Association (MDA, grant 577497), the Association Française contre les Myopathies (AFM, grant 21533), the Association Belge contre les Maladies Neuromusculaires (ABMM), the Medical Foundation Queen Elisabeth (GSKE), the EC 7th Framework Programme NEUROMICS, "Integrated Europeanomics research project for diagnosis and therapy in rare neuromuscular and neurodegenerative diseases" (grant 2012-305121), and the H2020 grant Solve-RD programme "Solving the unsolved rare diseases" (grant 2017-779257).

Open Access This article is licensed under a Creative Commons Attribution 4.0 International License, which permits use, sharing, adaptation, distribution and reproduction in any medium or format, as long as you give appropriate credit to the original author(s) and the source, provide a link to the Creative Commons licence, and indicate if changes were made. The images or other third party material in this article are included in the article's Creative Commons licence, unless indicated otherwise in a credit line to the material. If material is not included in the article's Creative Commons licence and your intended use is not permitted by statutory regulation or exceeds the permitted use, you will need to obtain permission directly from the copyright holder. To view a copy of this licence, visit http://creativecommons.org/licenses/by/4.0/.

\section{References}

Abisambra JF, Blair LJ, Hill SE, Jones JR, Kraft C, Rogers J, Koren J 3rd, Jinwal UK, Lawson L, Johnson AG, Wilcock D, O'Leary JC, Jansen-West K, Muschol M, Golde TE, Weeber EJ, Banko J, Dickey CA (2010) Phosphorylation dynamics regulate Hsp27mediated rescue of neuronal plasticity deficits in tau transgenic mice. J Neurosci 30:15374-15382

Ackerley S, James PA, Kalli A, French S, Davies KE, Talbot K (2006) A mutation in the small heat-shock protein HSPB1 leading to distal hereditary motor neuronopathy disrupts neurofilament assembly and the axonal transport of specific cellular cargoes. Hum Mol Genet 15: 347-354

Adriaenssens E, Geuens T, Baets J, Echaniz-Laguna A, Timmerman V (2017) Novel insights in the disease biology of mutant small heat shock proteins in neuromuscular diseases. Brain 140:2541-2549

Alderson TR, Roche J, Gastall HY, Dias DM, Pritisanac I, Ying J, Bax A, Benesch JLP, Baldwin AJ (2019) Local unfolding of the HSP27 monomer regulates chaperone activity. Nat Commun 10:1068

Almeida-Souza L, Goethals S, de Winter V, Dierick I, Gallardo R, Van Durme J, Irobi J, Gettemans J, Rousseau F, Schymkowitz J, Timmerman V, Janssens S (2010) Increased monomerization of mutant HSPB1 leads to protein hyperactivity in Charcot-Marie-Tooth neuropathy. J Biol Chem 285:12778-12786 
Almeida-Souza L, Asselbergh B, d'Ydewalle C, Moonens K, Goethals S, de Winter V, Azmi A, Irobi J, Timmermans JP, Gevaert K, Remaut H, Van Den Bosch L, Timmerman V, Janssens S (2011) Small heatshock protein HSPB1 mutants stabilize microtubules in CharcotMarie-Tooth neuropathy. J Neurosci 31:15320-15328

Almeida-Souza L, Asselbergh B, De Winter V, Goethals S, Timmerman V, Janssens S (2013) HSPB1 facilitates the formation of noncentrosomal microtubules. PLoS One 8:e66541

Al-Sarraj S, King A, Troakes C, Smith B, Maekawa S, Bodi I, Rogelj B, Al-Chalabi A, Hortobagyi T, Shaw CE (2011) p62 positive, TDP-43 negative, neuronal cytoplasmic and intranuclear inclusions in the cerebellum and hippocampus define the pathology of C9orf72linked FTLD and MND/ALS. Acta Neuropathol 122:691-702

An JJ, Lee YP, Kim DW, Sohn EJ, Jeong HJ, Kang HW, Shin MJ, Kim MJ, Ahn EH, Jang SH, Kang JH, Kang TC, Won MH, Kwon OS, Cho SW, Lee KS, Park J, Eum WS, Choi SY (2009) Transduced HSP27 protein protects neuronal cell death by enhancing FALSassociated SOD1 mutant activity. BMB Rep 42:136-141

Anagnostou G, Akbar MT, Paul P, Angelinetta C, Steiner TJ, de Belleroche J (2010) Vesicle associated membrane protein B (VAPB) is decreased in ALS spinal cord. Neurobiol Aging 31: 969-985

Ash PE, Bieniek KF, Gendron TF, Caulfield T, Lin WL, DejesusHernandez M, van Blitterswijk MM, Jansen-West K, Paul JW 3rd, Rademakers R, Boylan KB, Dickson DW, Petrucelli L (2013) Unconventional translation of C9ORF72 GGGGCC expansion generates insoluble polypeptides specific to c9FTD/ALS. Neuron 77: 639-646

Ashizawa T, Oz G, Paulson HL (2018) Spinocerebellar ataxias: prospects and challenges for therapy development. Nat Rev Neurol 14:590 605

Baldwin AJ, Lioe H, Robinson CV, Kay LE, Benesch JL (2011) alphaBcrystallin polydispersity is a consequence of unbiased quaternary dynamics. J Mol Biol 413: 297-309

Ballatore C, Lee VM, Trojanowski JQ (2007) Tau-mediated neurodegeneration in Alzheimer's disease and related disorders. Nat Rev Neurosci 8:663-672

Baughman HER, Clouser AF, Klevit RE, Nath A (2018) HspB1 and Hsc70 chaperones engage distinct tau species and have different inhibitory effects on amyloid formation. J Biol Chem 293:26872700

Benedetti S, Previtali SC, Coviello S, Scarlato M, Cerri F, Di Pierri E, Piantoni L, Spiga I, Fazio R, Riva N, Natali Sora MG, Dacci P, Malaguti MC, Munerati E, Grimaldi LM, Marrosu MG, De Pellegrin M, Ferrari M, Comi G, Quattrini A et al (2010) Analyzing histopathological features of rare charcot-marie-tooth neuropathies to unravel their pathogenesis. Arch Neurol 67:14981505

Benilova I, Karran E, De Strooper B (2012) The toxic Abeta oligomer and Alzheimer's disease: an emperor in need of clothes. Nat Neurosci 15:349-357

Bepperling A, Alte F, Kriehuber T, Braun N, Weinkauf S, Groll M, Haslbeck M, Buchner J (2012) Alternative bacterial twocomponent small heat shock protein systems. Proc Natl Acad Sci U S A 109:20407-20412

Berger Z, Roder H, Hanna A, Carlson A, Rangachari V, Yue M, Wszolek Z, Ashe K, Knight J, Dickson D, Andorfer C, Rosenberry TL, Lewis J, Hutton M, Janus C (2007) Accumulation of pathological tau species and memory loss in a conditional model of tauopathy. $\mathrm{J}$ Neurosci 27:3650-3662

Bilen J, Bonini NM (2007) Genome-wide screen for modifiers of ataxin-3 neurodegeneration in Drosophila. PLoS Genet 3:1950-1964

Bjorkdahl C, Sjogren MJ, Zhou X, Concha H, Avila J, Winblad B, Pei JJ (2008) Small heat shock proteins Hsp27 or alphaB-crystallin and the protein components of neurofibrillary tangles: tau and neurofilaments. J Neurosci Res 86:1343-1352
Blancas-Mejia LM, Ramirez-Alvarado M (2013) Systemic amyloidoses. Annu Rev Biochem 82:745-774

Boeynaems S, Alberti S, Fawzi NL, Mittag T, Polymenidou M, Rousseau F, Schymkowitz J, Shorter J, Wolozin B, Van Den Bosch L, Tompa P, Fuxreiter M (2018) Protein phase separation: a new phase in cell biology. Trends Cell Biol 28:420-435

Bouhy D, Juneja M, Katona I, Holmgren A, Asselbergh B, De Winter V, Hochepied T, Goossens S, Haigh JJ, Libert C, Ceuterick-de Groote C, Irobi J, Weis J, Timmerman V (2018) A knock-in/knock-out mouse model of HSPB8-associated distal hereditary motor neuropathy and myopathy reveals toxic gain-of-function of mutant $\mathrm{Hspb8}$. Acta Neuropathol 135:131-148

Boxer AL, Mackenzie IR, Boeve BF, Baker M, Seeley WW, Crook R, Feldman H, Hsiung GY, Rutherford N, Laluz V, Whitwell J, Foti D, McDade E, Molano J, Karydas A, Wojtas A, Goldman J, Mirsky J, Sengdy P, Dearmond S et al (2011) Clinical, neuroimaging and neuropathological features of a new chromosome 9p-linked FTDALS family. J Neurol Neurosurg Psychiatry 82:196-203

Bruinsma IB, Bruggink KA, Kinast K, Versleijen AA, Segers-Nolten IM, Subramaniam V, Kuiperij HB, Boelens W, de Waal RM, Verbeek MM (2011) Inhibition of alpha-synuclein aggregation by small heat shock proteins. Proteins 79:2956-2967

Bucciantini M, Giannoni E, Chiti F, Baroni F, Formigli L, Zurdo J, Taddei N, Ramponi G, Dobson CM, Stefani M (2002) Inherent toxicity of aggregates implies a common mechanism for protein misfolding diseases. Nature 416:507-511

Cameron RT, Quinn SD, Cairns LS, MacLeod R, Samuel ID, Smith BO, Carlos Penedo J, Baillie GS (2014) The phosphorylation of Hsp20 enhances its association with amyloid-beta to increase protection against neuronal cell death. Mol Cell Neurosci 61:46-55

Capponi S, Geroldi A, Fossa P, Grandis M, Ciotti P, Gulli R, Schenone A, Mandich P, Bellone E (2011) HSPB1 and HSPB8 in inherited neuropathies: study of an Italian cohort of dHMN and CMT2 patients. J Peripher Nerv Syst 16:287-294

Capponi S, Geuens T, Geroldi A, Origone P, Verdiani S, Cichero E, Adriaenssens E, De Winter V, Bandettini di Poggio M, Barberis M, Chio A, Fossa P, Mandich P, Bellone E, Timmerman V (2016) Molecular chaperones in the pathogenesis of amyotrophic lateral sclerosis: the role of HSPB1. Hum Mutat 37:1202-1208

Carra S (2009) The stress-inducible HspB8-Bag3 complex induces the eIF2alpha kinase pathway: implications for protein quality control and viral factory degradation? Autophagy 5:428-429

Carra S, Sivilotti M, Chavez Zobel AT, Lambert H, Landry J (2005) HspB8, a small heat shock protein mutated in human neuromuscular disorders, has in vivo chaperone activity in cultured cells. Hum Mol Genet 14:1659-1669

Carra S, Seguin SJ, Landry J (2008) HspB8 and Bag3: a new chaperone complex targeting misfolded proteins to macroautophagy. Autophagy 4:237-239

Carra S, Brunsting JF, Lambert H, Landry J, Kampinga HH (2009) HspB8 participates in protein quality control by a non-chaperonelike mechanism that requires eIF2 \{alpha\} phosphorylation. J Biol Chem 284:5523-5532

Carra S, Boncoraglio A, Kanon B, Brunsting JF, Minoia M, Rana A, Vos MJ, Seidel K, Sibon OC, Kampinga HH (2010) Identification of the Drosophila ortholog of HSPB8: implication of HSPB8 loss of function in protein folding diseases. J Biol Chem 285:37811-37822

Carra S, Rusmini P, Crippa V, Giorgetti E, Boncoraglio A, Cristofani R, Naujock M, Meister M, Minoia M, Kampinga HH, Poletti A (2013) Different anti-aggregation and pro-degradative functions of the members of the mammalian sHSP family in neurological disorders. Philos Trans R Soc Lond Ser B Biol Sci 368:20110409

Carra S, Alberti S, Benesch JLP, Boelens W, Buchner J, Carver JA, Cecconi C, Ecroyd H, Gusev N, Hightower LE, Klevit RE, Lee HO, Liberek K, Lockwood B, Poletti A, Timmerman V, Toth ME, Vierling E, Wu T, Tanguay RM (2019) Small heat shock proteins: 
multifaceted proteins with important implications for life. Cell Stress Chaperones 24(2):295-308

Caughey B, Lansbury PT (2003) Protofibrils, pores, fibrils, and neurodegeneration: separating the responsible protein aggregates from the innocent bystanders. Annu Rev Neurosci 26:267-298

Chalova AS, Sudnitsyna MV, Strelkov SV, Gusev NB (2014) Characterization of human small heat shock protein HspB1 that carries C-terminal domain mutations associated with hereditary motor neuron diseases. Biochim Biophys Acta 1844:2116-2126

Cha-Molstad H, Yu JE, Feng Z, Lee SH, Kim JG, Yang P, Han B, Sung KW, Yoo YD, Hwang J, McGuire T, Shim SM, Song HD, Ganipisetti S, Wang N, Jang JM, Lee MJ, Kim SJ, Lee KH, Hong JT et al (2017) p62/SQSTM1/Sequestosome-1 is an N-recognin of the $\mathrm{N}$-end rule pathway which modulates autophagosome biogenesis. Nat Commun 8:102

Charette SJ, Lavoie JN, Lambert H, Landry J (2000) Inhibition of Daxxmediated apoptosis by heat shock protein 27. Mol Cell Biol 20: 7602-7612

Chen SF, Kang ML, Chen YC, Tang HW, Huang CW, Li WH, Lin CP, Wang CY, Wang PY, Chen GC, Wang HD (2012) Autophagyrelated gene 7 is downstream of heat shock protein 27 in the regulation of eye morphology, polyglutamine toxicity, and lifespan in Drosophila. J Biomed Sci 19:52

Chuang E, Hori AM, Hesketh CD, Shorter J (2018) Amyloid assembly and disassembly. J Cell Sci 131(8):jcs189928

Chung KW, Kim SB, Cho SY, Hwang SJ, Park SW, Kang SH, Kim J, Yoo JH, Choi BO (2008) Distal hereditary motor neuropathy in Korean patients with a small heat shock protein 27 mutation. Exp Mol Med 40:304-312

Cicardi ME, Cristofani R, Rusmini P, Meroni M, Ferrari V, Vezzoli G, Tedesco B, Piccolella M, Messi E, Galbiati M, Boncoraglio A, Carra S, Crippa V, Poletti A (2018) Tdp-25 routing to autophagy and proteasome ameliorates its aggregation in amyotrophic lateral sclerosis target cells. Sci Rep 8:12390

Ciuffa R, Lamark T, Tarafder AK, Guesdon A, Rybina S, Hagen WJ, Johansen T, Sachse C (2015) The selective autophagy receptor p62 forms a flexible filamentous helical scaffold. Cell Rep 11: $748-758$

Clark AR, Vree Egberts W, Kondrat FDL, Hilton GR, Ray NJ, Cole AR, Carver JA, Benesch JLP, Keep NH, Boelens WC, Slingsby C (2018) Terminal regions confer plasticity to the tetrameric assembly of human HspB2 and HspB3. J Mol Biol 430:3297-3310

Clarke JP, Mearow KM (2013) Cell stress promotes the association of phosphorylated HspB1 with F-actin. PLoS One 8:e68978

Cox D, Ecroyd H (2017) The small heat shock proteins alphaB-crystallin (HSPB5) and Hsp27 (HSPB1) inhibit the intracellular aggregation of alpha-synuclein. Cell Stress Chaperones 22:589-600

Cox D, Selig E, Griffin MD, Carver JA, Ecroyd H (2016) Small heatshock proteins prevent alpha-synuclein aggregation via transient interactions and their efficacy is affected by the rate of aggregation. J Biol Chem 291:22618-22629

Cox D, Whiten DR, Brown JWP, Horrocks MH, San Gil R, Dobson CM, Klenerman D, van Oijen AM, Ecroyd H (2018) The small heat shock protein Hsp27 binds alpha-synuclein fibrils, preventing elongation and cytotoxicity. J Biol Chem 293:4486-4497

Crippa V, Sau D, Rusmini P, Boncoraglio A, Onesto E, Bolzoni E, Galbiati M, Fontana E, Marino M, Carra S, Bendotti C, De Biasi S, Poletti A (2010) The small heat shock protein B8 (HspB8) promotes autophagic removal of misfolded proteins involved in amyotrophic lateral sclerosis (ALS). Hum Mol Genet 19:3440-3456

Crippa V, Galbiati M, Boncoraglio A, Rusmini P, Onesto E, Giorgetti E, Cristofani R, Zito A, Poletti A (2013) Motoneuronal and muscleselective removal of ALS-related misfolded proteins. Biochem Soc Trans 41:1598-1604

Crippa V, Cicardi ME, Ramesh N, Seguin SJ, Ganassi M, Bigi I, Diacci C, Zelotti E, Baratashvili M, Gregory JM, Dobson CM, Cereda C,
Pandey UB, Poletti A, Carra S (2016a) The chaperone HSPB8 reduces the accumulation of truncated TDP-43 species in cells and protects against TDP-43-mediated toxicity. Hum Mol Genet 25: 3908-3924

Crippa V, D’Agostino VG, Cristofani R, Rusmini P, Cicardi ME, Messi E, Loffredo R, Pancher M, Piccolella M, Galbiati M, Meroni M, Cereda C, Carra S, Provenzani A, Poletti A (2016b) Transcriptional induction of the heat shock protein $\mathrm{B} 8$ mediates the clearance of misfolded proteins responsible for motor neuron diseases. Sci Rep 6:22827

Cristofani R, Crippa V, Rusmini P, Cicardi ME, Meroni M, Licata NV, Sala G, Giorgetti E, Grunseich C, Galbiati M, Piccolella M, Messi E, Ferrarese C, Carra S, Poletti A (2017) Inhibition of retrograde transport modulates misfolded protein accumulation and clearance in motoneuron diseases. Autophagy 13:1280-1303

Cristofani R, Crippa V, Vezzoli G, Rusmini P, Galbiati M, Cicardi ME, Meroni M, Ferrari V, Tedesco B, Piccolella M, Messi E, Carra S, Poletti A (2018) The small heat shock protein B8 (HSPB8) efficiently removes aggregating species of dipeptides produced in C9ORF72-related neurodegenerative diseases. Cell Stress Chaperones 23:1-12

Cuesta R, Laroia G, Schneider RJ (2000) Chaperone hsp27 inhibits translation during heat shock by binding eIF4G and facilitating dissociation of cap-initiation complexes. Genes Dev 14:1460-1470

d'Ydewalle C, Krishnan J, Chiheb DM, Van Damme P, Irobi J, Kozikowski AP, Vanden Berghe P, Timmerman V, Robberecht W, Van Den Bosch L (2011) HDAC6 inhibitors reverse axonal loss in a mouse model of mutant HSPB1-induced Charcot-Marie-Tooth disease. Nat Med 17:968-974

Dehle FC, Ecroyd H, Musgrave IF, Carver JA (2010) alphaB-Crystallin inhibits the cell toxicity associated with amyloid fibril formation by kappa-casein and the amyloid-beta peptide. Cell Stress Chaperones 15:1013-1026

DeJesus-Hernandez M, Mackenzie IR, Boeve BF, Boxer AL, Baker M, Rutherford NJ, Nicholson AM, Finch NA, Flynn H, Adamson J, Kouri N, Wojtas A, Sengdy P, Hsiung GY, Karydas A, Seeley WW, Josephs KA, Coppola G, Geschwind DH, Wszolek ZK et al (2011) Expanded GGGGCC hexanucleotide repeat in noncoding region of C9ORF72 causes chromosome 9p-linked FTD and ALS. Neuron 72:245-256

den Engelsman J, Boros S, Dankers PY, Kamps B, Vree Egberts WT, Bode CS, Lane LA, Aquilina JA, Benesch JL, Robinson CV, de Jong WW, Boelens WC (2009) The small heat-shock proteins HSPB2 and HSPB3 form well-defined heterooligomers in a unique 3 to 1 subunit ratio. J Mol Biol 393:1022-1032

Deng HX, Hentati A, Tainer JA, Iqbal Z, Cayabyab A, Hung WY, Getzoff ED, Hu P, Herzfeldt B, Roos RP et al (1993) Amyotrophic lateral sclerosis and structural defects in $\mathrm{Cu}, \mathrm{Zn}$ superoxide dismutase. Science 261:1047-1051

Deng HX, Zhai H, Bigio EH, Yan J, Fecto F, Ajroud K, Mishra M, Ajroud-Driss S, Heller S, Sufit R, Siddique N, Mugnaini E, Siddique T (2010) FUS-immunoreactive inclusions are a common feature in sporadic and non-SOD1 familial amyotrophic lateral sclerosis. Ann Neurol 67:739-748

Deng H, Gao K, Jankovic J (2014) The role of FUS gene variants in neurodegenerative diseases. Nat Rev Neurol 10:337-348

Der Perng M, Quinlan RA (2004) Neuronal diseases: small heat shock proteins calm your nerves. Curr Biol 14:R625-R626

Dierick I, Irobi J, Janssens S, Theuns J, Lemmens R, Jacobs A, Corsmit E, Hersmus N, Van Den Bosch L, Robberecht W, De Jonghe P, Van Broeckhoven C, Timmerman V (2007) Genetic variant in the HSPB1 promoter region impairs the HSP27 stress response. Hum Mutat 28:830

Dierick I, Baets J, Irobi J, Jacobs A, De Vriendt E, Deconinck T, Merlini L, Van den Bergh P, Rasic VM, Robberecht W, Fischer D, Morales RJ, Mitrovic Z, Seeman P, Mazanec R, Kochanski A, Jordanova A, 
Auer-Grumbach M, Helderman-van den Enden AT, Wokke JH et al (2008) Relative contribution of mutations in genes for autosomal dominant distal hereditary motor neuropathies: a genotypephenotype correlation study. Brain 131:1217-1227

Duennwald ML, Echeverria A, Shorter J (2012) Small heat shock proteins potentiate amyloid dissolution by protein disaggregases from yeast and humans. PLoS Biol 10:e1001346

Echaniz-Laguna A, Geuens T, Petiot P, Pereon Y, Adriaenssens E, Haidar M, Capponi S, Maisonobe T, Fournier E, Dubourg O, Degos B, Salachas F, Lenglet T, Eymard B, Delmont E, Pouget J, Juntas Morales R, Goizet C, Latour P, Timmerman V et al (2017a) Axonal neuropathies due to mutations in small heat shock proteins: clinical, genetic, and functional insights into novel mutations. Hum Mutat 38:556-568

Echaniz-Laguna A, Lornage X, Lannes B, Schneider R, Bierry G, Dondaine N, Boland A, Deleuze JF, Bohm J, Thompson J, Laporte J, Biancalana V (2017b) HSPB8 haploinsufficiency causes dominant adult-onset axial and distal myopathy. Acta Neuropathol 134:163-165

Eenjes E, Dragich JM, Kampinga HH, Yamamoto A (2016) Distinguishing aggregate formation and aggregate clearance using cell-based assays. J Cell Sci 129:1260-1270

Eisenberg D, Jucker M (2012) The amyloid state of proteins in human diseases. Cell 148:1188-1203

El-Kadi AM, Bros-Facer V, Deng W, Philpott A, Stoddart E, Banks G, Jackson GS, Fisher EM, Duchen MR, Greensmith L, Moore AL, Hafezparast M (2010) The legs at odd angles (Loa) mutation in cytoplasmic dynein ameliorates mitochondrial function in SOD1G93A mouse model for motor neuron disease. J Biol Chem 285:18627-18639

Evgrafov OV, Mersiyanova I, Irobi J, Van Den Bosch L, Dierick I, Leung CL, Schagina O, Verpoorten N, Van Impe K, Fedotov V, Dadali E, Auer-Grumbach M, Windpassinger C, Wagner K, Mitrovic Z, Hilton-Jones D, Talbot K, Martin JJ, Vasserman N, Tverskaya S et al (2004) Mutant small heat-shock protein 27 causes axonal Charcot-Marie-Tooth disease and distal hereditary motor neuropathy. Nat Genet 36:602-606

Fleckenstein T, Kastenmuller A, Stein ML, Peters C, Daake M, Krause M, Weinfurtner D, Haslbeck M, Weinkauf S, Groll M, Buchner J (2015) The chaperone activity of the developmental small heat shock protein Sip1 is regulated by $\mathrm{pH}$-dependent conformational changes. Mol Cell 58:1067-1078

Fortunato F, Neri M, Geroldi A, Bellone E, De Grandis D, Ferlini A, Gualandi F (2017) A CMT2 family carrying the P7R mutation in the N-terminal region of the HSPB1 gene. Clin Neurol Neurosurg 163:15-17

Fowler DM, Koulov AV, Balch WE, Kelly JW (2007) Functional amyloid-from bacteria to humans. Trends Biochem Sci 32:217-224

Franzmann TM, Wuhr M, Richter K, Walter S, Buchner J (2005) The activation mechanism of $\mathrm{Hsp} 26$ does not require dissociation of the oligomer. J Mol Biol 350:1083-1093

Freibaum BD, Taylor JP (2017) The role of dipeptide repeats in C9ORF72-related ALS-FTD. Front Mol Neurosci 10:35

Freilich R, Betegon M, Tse E, Mok SA, Julien O, Agard DA, Southworth DR, Takeuchi K, Gestwicki JE (2018) Competing protein-protein interactions regulate binding of Hsp27 to its client protein tau. Nat Commun 9:4563

Fuchs M, Poirier DJ, Seguin SJ, Lambert H, Carra S, Charette SJ, Landry $J$ (2009) Identification of the key structural motifs involved in HspB8/HspB6-Bag3 interaction. Biochem J 425:245-255

Fuchs M, Luthold C, Guilbert SM, Varlet AA, Lambert H, Jette A, Elowe S, Landry J, Lavoie JN (2015) A role for the chaperone complex BAG3-HSPB8 in actin dynamics, spindle orientation and proper chromosome segregation during mitosis. PLoS Genet 11:e1005582

Fusco G, De Simone A, Gopinath T, Vostrikov V, Vendruscolo M, Dobson CM, Veglia G (2014) Direct observation of the three regions in alpha-synuclein that determine its membrane-bound behaviour. Nat Commun 5:3827

Gaeta M, Mileto A, Mazzeo A, Minutoli F, Di Leo R, Settineri N, Donato R, Ascenti G, Blandino A (2012) MRI findings, patterns of disease distribution, and muscle fat fraction calculation in five patients with Charcot-Marie-Tooth type 2 F disease. Skelet Radiol 41:515-524

Ganassi M, Mateju D, Bigi I, Mediani L, Poser I, Lee HO, Seguin SJ, Morelli FF, Vinet J, Leo G, Pansarasa O, Cereda C, Poletti A, Alberti S, Carra S (2016) A surveillance function of the HSPB8-BAG3HSP70 chaperone complex ensures stress granule integrity and dynamism. Mol Cell 63:796-810

Geuens T, De Winter V, Rajan N, Achsel T, Mateiu L, Almeida-Souza L, Asselbergh B, Bouhy D, Auer-Grumbach M, Bagni C, Timmerman V (2017) Mutant HSPB1 causes loss of translational repression by binding to PCBP1, an RNA binding protein with a possible role in neurodegenerative disease. Acta Neuropathol Commun 5:5

Ghaoui R, Palmio J, Brewer J, Lek M, Needham M, Evila A, Hackman P, Jonson PH, Penttila S, Vihola A, Huovinen S, Lindfors M, Davis RL, Waddell L, Kaur S, Yiannikas C, North K, Clarke N, MacArthur DG, Sue CM et al (2016) Mutations in HSPB8 causing a new phenotype of distal myopathy and motor neuropathy. Neurology 86 : 391-398

Gijselinck I, Van Langenhove T, van der Zee J, Sleegers K, Philtjens S, Kleinberger G, Janssens J, Bettens K, Van Cauwenberghe C, Pereson S, Engelborghs S, Sieben A, De Jonghe P, Vandenberghe R, Santens P, De Bleecker J, Maes G, Baumer V, Dillen L, Joris G et al (2012) A C9orf72 promoter repeat expansion in a FlandersBelgian cohort with disorders of the frontotemporal lobar degeneration-amyotrophic lateral sclerosis spectrum: a gene identification study. Lancet Neurol 11:54-65

Goedert M, Masuda-Suzukake M, Falcon B (2017) Like prions: the propagation of aggregated tau and alpha-synuclein in neurodegeneration. Brain 140:266-278

Goldstein LE, Muffat JA, Cherny RA, Moir RD, Ericsson MH, Huang X, Mavros C, Coccia JA, Faget KY, Fitch KA, Masters CL, Tanzi RE, Chylack LT Jr, Bush AI (2003) Cytosolic beta-amyloid deposition and supranuclear cataracts in lenses from people with Alzheimer's disease. Lancet 361:1258-1265

Gray M, Shirasaki DI, Cepeda C, Andre VM, Wilburn B, Lu XH, Tao J, Yamazaki I, Li SH, Sun YE, Li XJ, Levine MS, Yang XW (2008) Full-length human mutant huntingtin with a stable polyglutamine repeat can elicit progressive and selective neuropathogenesis in BACHD mice. J Neurosci 28:6182-6195

group THsdcr (1993) A novel gene containing a trinucleotide repeat that is expanded and unstable on Huntington's disease chromosomes. The Huntington's Disease Collaborative Research Group. Cell 72: 971-983

Guilbert SM, Lambert H, Rodrigue MA, Fuchs M, Landry J, Lavoie JN (2018) HSPB8 and BAG3 cooperate to promote spatial sequestration of ubiquitinated proteins and coordinate the cellular adaptive response to proteasome insufficiency. FASEB J 32:3518-3535

Guo JL, Lee VM (2014) Cell-to-cell transmission of pathogenic proteins in neurodegenerative diseases. Nat Med 20:130-138

Guo L, Shorter J (2017) Biology and Pathobiology of TDP-43 and Emergent Therapeutic Strategies. Cold Spring Harb Perspect Med 7(9):a024554

Haidar M, Asselbergh B, Adriaenssens E, De Winter V, Timmermans JP, Auer-Grumbach M, Juneja M, Timmerman V (2019) Neuropathycausing mutations in HSPB1 impair autophagy by disturbing the formation of SQSTM1/p62 bodies. Autophagy 15(6):1051-1068

Hardiman O, Al-Chalabi A, Chio A, Corr EM, Logroscino G, Robberecht W, Shaw PJ, Simmons Z, van den Berg LH (2017) Amyotrophic lateral sclerosis. Nat Rev Dis Primers 3:17071

Harding AE, Thomas PK (1980) The clinical features of hereditary motor and sensory neuropathy types I and II. Brain 103:259-280 
Haslbeck M, Vierling E (2015) A first line of stress defense: small heat shock proteins and their function in protein homeostasis. J Mol Biol 427:1537-1548

Haslbeck M, Franzmann T, Weinfurtner D, Buchner J (2005) Some like it hot: the structure and function of small heat-shock proteins. Nat Struct Mol Biol 12:842-846

Hay DG, Sathasivam K, Tobaben S, Stahl B, Marber M, Mestril R, Mahal A, Smith DL, Woodman B, Bates GP (2004) Progressive decrease in chaperone protein levels in a mouse model of Huntington's disease and induction of stress proteins as a therapeutic approach. Hum Mol Genet 13:1389-1405

Heilman PL, Song S, Miranda CJ, Meyer K, Srivastava AK, Knapp A, Wier CG, Kaspar BK, Kolb SJ (2017) HSPB1 mutations causing hereditary neuropathy in humans disrupt non-cell autonomous protection of motor neurons. Exp Neurol 297:101-109

Hishiya A, Salman MN, Carra S, Kampinga HH, Takayama S (2011) BAG3 directly interacts with mutated alphaB-crystallin to suppress its aggregation and toxicity. PLoS One 6:e16828

Holmgren A, Bouhy D, De Winter V, Asselbergh B, Timmermans JP, Irobi J, Timmerman V (2013) Charcot-Marie-Tooth causing HSPB1 mutations increase Cdk5-mediated phosphorylation of neurofilaments. Acta Neuropathol 126:93-108

Hong Y, Zhao T, Li XJ, Li S (2017) Mutant Huntingtin inhibits alphaBcrystallin expression and impairs exosome secretion from astrocytes. J Neurosci 37:9550-9563

Houlden H, Laura M, Wavrant-De Vrieze F, Blake J, Wood N, Reilly MM (2008) Mutations in the HSP27 (HSPB1) gene cause dominant, recessive, and sporadic distal HMN/CMT type 2. Neurology 71: $1660-1668$

Huttenrauch M, Brauss A, Kurdakova A, Borgers H, Klinker F, Liebetanz D, Salinas-Riester G, Wiltfang J, Klafki HW, Wirths O (2016) Physical activity delays hippocampal neurodegeneration and rescues memory deficits in an Alzheimer disease mouse model. Transl Psychiatry 6:e800

Ikeda Y, Abe A, Ishida C, Takahashi K, Hayasaka K, Yamada M (2009) A clinical phenotype of distal hereditary motor neuronopathy type II with a novel HSPB1 mutation. J Neurol Sci 277:9-12

Irobi J, Van Impe K, Seeman P, Jordanova A, Dierick I, Verpoorten N, Michalik A, De Vriendt E, Jacobs A, Van Gerwen V, Vennekens K, Mazanec R, Tournev I, Hilton-Jones D, Talbot K, Kremensky I, Van Den Bosch L, Robberecht W, Van Vandekerckhove J, Van Broeckhoven C et al (2004) Hot-spot residue in small heat-shock protein 22 causes distal motor neuropathy. Nat Genet 36:597-601

Irobi J, Holmgren A, De Winter V, Asselbergh B, Gettemans J, Adriaensen D, Ceuterick-de Groote C, Van Coster R, De Jonghe P, Timmerman V (2012) Mutant HSPB8 causes protein aggregates and a reduced mitochondrial membrane potential in dermal fibroblasts from distal hereditary motor neuropathy patients. NeuromuscDisord 22:699-711

Iwaki T, Wisniewski T, Iwaki A, Corbin E, Tomokane N, Tateishi J, Goldman JE (1992) Accumulation of alpha B-crystallin in central nervous system glia and neurons in pathologic conditions. Am J Pathol 140:345-356

James PA, Rankin J, Talbot K (2008) Asymmetrical late onset motor neuropathy associated with a novel mutation in the small heat shock protein HSPB1 (HSP27). J Neurol Neurosurg Psychiatry 79:461463

Jovcevski B, Kelly MA, Rote AP, Berg T, Gastall HY, Benesch JL, Aquilina JA, Ecroyd H (2015) Phosphomimics destabilize Hsp27 oligomeric assemblies and enhance chaperone activity. Chem Biol 22:186-95

Juneja M, Burns J, Saporta MA, Timmerman V (2019) Challenges in modelling the Charcot-Marie-Tooth neuropathies for therapy development. J Neurol Neurosurg Psychiatry 90:58-67

Kalmar B, Innes A, Wanisch K, Kolaszynska AK, Pandraud A, Kelly G, Abramov AY, Reilly MM, Schiavo G, Greensmith L (2017)
Mitochondrial deficits and abnormal mitochondrial retrograde axonal transport play a role in the pathogenesis of mutant Hsp27induced Charcot Marie Tooth disease. Hum Mol Genet 26:33133326

Kampinga HH, Bergink S (2016) Heat shock proteins as potential targets for protective strategies in neurodegeneration. Lancet Neurol 15: $748-759$

Kedersha N, Anderson P (2002) Stress granules: sites of mRNA triage that regulate mRNA stability and translatability. Biochem Soc Trans 30:963-969

Kijima K, Numakura C, Goto T, Takahashi T, Otagiri T, Umetsu K, Hayasaka K (2005) Small heat shock protein 27 mutation in a Japanese patient with distal hereditary motor neuropathy. J Hum Genet 50:473-476

Klucken J, Shin Y, Masliah E, Hyman BT, McLean PJ (2004) Hsp70 reduces alpha-synuclein aggregation and toxicity. J Biol Chem 279:25497-25502

Kolb SJ, Snyder PJ, Poi EJ, Renard EA, Bartlett A, Gu S, Sutton S, Arnold WD, Freimer ML, Lawson VH, Kissel JT, Prior TW (2010) Mutant small heat shock protein B3 causes motor neuropathy: utility of a candidate gene approach. Neurology 74:502-506

Krishnan J, Vannuvel K, Andries M, Waelkens E, Robberecht W, Van Den Bosch L (2008) Over-expression of Hsp27 does not influence disease in the mutant SOD1(G93A) mouse model of amyotrophic lateral sclerosis. J Neurochem 106:2170-2183

Kwok AS, Phadwal K, Turner BJ, Oliver PL, Raw A, Simon AK, Talbot K, Agashe VR (2011) HspB8 mutation causing hereditary distal motor neuropathy impairs lysosomal delivery of autophagosomes. J Neurochem 119:1155-1161

La Padula V, Staszewski O, Nestel S, Busch H, Boerries M, Roussa E, Prinz M, Krieglstein K (2016) HSPB3 protein is expressed in motoneurons and induces their survival after lesion-induced degeneration. Exp Neurol 286:40-49

Lassuthova P, Safka Brozkova D, Krutova M, Neupauerova J, Haberlova J, Mazanec R, Drimal P, Seeman P (2016) Improving diagnosis of inherited peripheral neuropathies through gene panel analysis. Orphanet J Rare Dis 11:118

Lee VM, Goedert M, Trojanowski JQ (2001) Neurodegenerative tauopathies. Annu Rev Neurosci 24:1121-1159

Lee EB, Lee VM, Trojanowski JQ (2011) Gains or losses: molecular mechanisms of TDP43-mediated neurodegeneration. Nat Rev Neurosci 13:38-50

Liao PC, Lin HY, Yuh CH, Yu LK, Wang HD (2008) The effect of neuronal expression of heat shock proteins 26 and 27 on lifespan, neurodegeneration, and apoptosis in Drosophila. Biochem Biophys Res Commun 376:637-641

Lin KP, Soong BW, Yang CC, Huang LW, Chang MH, Lee IH, Antonellis A, Lee YC (2011) The mutational spectrum in a cohort of CharcotMarie-Tooth disease type 2 among the Han Chinese in Taiwan. PLoS One 6:e29393

Lindberg I, Shorter J, Wiseman RL, Chiti F, Dickey CA, McLean PJ (2015) Chaperones in neurodegeneration. J Neurosci 35:1385313859

Liu Y, Zhou Q, Tang M, Fu N, Shao W, Zhang S, Yin Y, Zeng R, Wang X, Hu G, Zhou J (2015) Upregulation of alphaB-crystallin expression in the substantia nigra of patients with Parkinson's disease. Neurobiol Aging 36:1686-1691

Liu Z, Wang C, Li Y, Zhao C, Li T, Li D, Zhang S, Liu C (2018) Mechanistic insights into the switch of alphaB-crystallin chaperone activity and self-multimerization. J Biol Chem 293:14880-14890

Lowe J, Landon M, Pike I, Spendlove I, McDermott H, Mayer RJ (1990) Dementia with beta-amyloid deposition: involvement of alpha Bcrystallin supports two main diseases. Lancet 336:515-516

Luigetti M, Fabrizi GM, Madia F, Ferrarini M, Conte A, Del Grande A, Tasca G, Tonali PA, Sabatelli M (2010) A novel HSPB1 mutation in 
an Italian patient with CMT2/dHMN phenotype. J Neurol Sci 298: 114-117

Maatkamp A, Vlug A, Haasdijk E, Troost D, French PJ, Jaarsma D (2004) Decrease of Hsp25 protein expression precedes degeneration of motoneurons in ALS-SOD1 mice. Eur J Neurosci 20:14-28

Maeda K, Idehara R, Hashiguchi A, Takashima H (2014) A family with distal hereditary motor neuropathy and a K141Q mutation of small heat shock protein HSPB1. Intern Med 53:1655-1658

Maji SK, Perrin MH, Sawaya MR, Jessberger S, Vadodaria K, Rissman RA, Singru PS, Nilsson KP, Simon R, Schubert D, Eisenberg D, Rivier J, Sawchenko P, Vale W, Riek R (2009) Functional amyloids as natural storage of peptide hormones in pituitary secretory granules. Science 325:328-332

Mandich P, Grandis M, Varese A, Geroldi A, Acquaviva M, Ciotti P, Gulli R, Doria-Lamba L, Fabrizi GM, Giribaldi G, Pizzuti A, Schenone A, Bellone E (2010) Severe neuropathy after diphtheria-tetanuspertussis vaccination in a child carrying a novel frame-shift mutation in the small heat-shock protein 27 gene. J Child Neurol 25:107-109

Marrone L, Poser I, Casci I, Japtok J, Reinhardt P, Janosch A, Andree C, Lee HO, Moebius C, Koerner E, Reinhardt L, Cicardi ME, Hackmann K, Klink B, Poletti A, Alberti S, Bickle M, Hermann A, Pandey UB, Hyman AA et al (2018) Isogenic FUS-eGFP iPSC reporter lines enable quantification of FUS stress granule pathology that is rescued by drugs inducing autophagy. Stem Cell Reports 10: 375-389

Masino L, Nicastro G, Menon RP, Dal Piaz F, Calder L, Pastore A (2004) Characterization of the structure and the amyloidogenic properties of the Josephin domain of the polyglutamine-containing protein ataxin-3. J Mol Biol 344:1021-1035

Mateju D, Franzmann TM, Patel A, Kopach A, Boczek EE, Maharana S, Lee HO, Carra S, Hyman AA, Alberti S (2017) An aberrant phase transition of stress granules triggered by misfolded protein and prevented by chaperone function. EMBO J 36:1669-1687

Matsumoto T, Urushido M, Ide H, Ishihara M, Hamada-Ode K, Shimamura Y, Ogata K, Inoue K, Taniguchi Y, Taguchi T, Horino T, Fujimoto S, Terada Y (2015) Small heat shock protein beta-1 (HSPB1) is upregulated and regulates autophagy and apoptosis of renal tubular cells in acute kidney injury. PLoS One 10:e126229

McDonald ET, Bortolus M, Koteiche HA, McHaourab HS (2012) Sequence, structure, and dynamic determinants of Hsp27 (HspB1) equilibrium dissociation are encoded by the $\mathrm{N}$-terminal domain. Biochemistry 51:1257-1268

McLean PJ, Kawamata H, Shariff S, Hewett J, Sharma N, Ueda K, Breakefield XO, Hyman BT (2002) TorsinA and heat shock proteins act as molecular chaperones: suppression of alpha-synuclein aggregation. J Neurochem 83:846-854

Mizutani T, Inose T, Nakajima S, Kakimi S, Uchigata M, Ikeda K, Gambetti P, Takasu T (1998) Familial parkinsonism and dementia with ballooned neurons, argyrophilic neuronal inclusions, atypical neurofibrillary tangles, tau-negative astrocytic fibrillary tangles, and Lewy bodies. Acta Neuropathol 95:15-27

Mok SA, Condello C, Freilich R, Gillies A, Arhar T, Oroz J, Kadavath H, Julien O, Assimon VA, Rauch JN, Dunyak BM, Lee J, Tsai FTF, Wilson MR, Zweckstetter M, Dickey CA, Gestwicki JE (2018) Mapping interactions with the chaperone network reveals factors that protect against tau aggregation. Nat Struct Mol Biol 25:384-393

Morelli FF, Mediani L, Heldens L, Bertacchini J, Bigi I, Carra AD, Vinet J, Carra S (2017a) An interaction study in mammalian cells demonstrates weak binding of HSPB2 to BAG3, which is regulated by HSPB3 and abrogated by HSPB8. Cell Stress Chaperones 22:531540

Morelli FF, Verbeek DS, Bertacchini J, Vinet J, Mediani L, Marmiroli S, Cenacchi G, Nasi M, De Biasi S, Brunsting JF, Lammerding J, Pegoraro E, Angelini C, Tupler R, Alberti S, Carra S (2017b) Aberrant compartment formation by HSPB2 mislocalizes Lamin A and compromises nuclear integrity and function. Cell Rep 20:2100 2115

Mori K, Weng SM, Arzberger T, May S, Rentzsch K, Kremmer E, Schmid B, Kretzschmar HA, Cruts M, Van Broeckhoven C, Haass C, Edbauer D (2013) The C9orf72 GGGGCC repeat is translated into aggregating dipeptide-repeat proteins in FTLD/ALS. Science 339:1335-1338

Muchowski PJ, Wacker JL (2005) Modulation of neurodegeneration by molecular chaperones. Nat Rev Neurosci 6:11-22

Muchowski PJ, Ramsden R, Nguyen Q, Arnett EE, Greiling TM, Anderson SK, Clark JI (2008) Noninvasive measurement of protein aggregation by mutant huntingtin fragments or alpha-synuclein in the lens. J Biol Chem 283:6330-6336

Muranova LK, Weeks SD, Strelkov SV, Gusev NB (2015) Characterization of mutants of human small heat shock protein $\mathrm{HspB} 1$ carrying replacements in the N-terminal domain and associated with hereditary motor neuron diseases. PLoS One 10:e0126248

Mymrikov EV, Daake M, Richter B, Haslbeck M, Buchner J (2017) The chaperone activity and substrate spectrum of human small heat shock proteins. J Biol Chem 292:672-684

Nafar F, Williams JB, Mearow KM (2016) Astrocytes release HspB1 in response to amyloid-beta exposure in vitro. J Alzheimers Dis 49: 251-263

Nakhro K, Park JM, Kim YJ, Yoon BR, Yoo JH, Koo H, Choi BO, Chung KW (2013) A novel Lys141 Thr mutation in small heat shock protein 22 (HSPB8) gene in Charcot-Marie-Tooth disease type 2L. Neuromuscul Disord 23:656-663

Nam DE, Nam SH, Lee AJ, Hong YB, Choi BO, Chung KW (2018) Small heat shock protein B3 (HSPB3) mutation in an axonal Charcot-Marie-Tooth disease family. J Peripher Nerv Syst 23:60-66

Narayan P, Meehan S, Carver JA, Wilson MR, Dobson CM, Klenerman D (2012) Amyloid-beta oligomers are sequestered by both intracellular and extracellular chaperones. Biochemistry 51:9270-9276

Narayanan S, Kamps B, Boelens WC, Reif B (2006) alphaB-crystallin competes with Alzheimer's disease beta-amyloid peptide for peptide-peptide interactions and induces oxidation of AbetaMet35. FEBS Lett 580:5941-5946

Nefedova VV, Muranova LK, Sudnitsyna MV, Ryzhavskaya AS, Gusev NB (2015) Small heat shock proteins and distal hereditary neuropathies. Biochemistry (Mosc) 80:1734-1747

Nemes Z, Devreese B, Steinert PM, Van Beeumen J, Fesus L (2004) Cross-linking of ubiquitin, HSP27, parkin, and alpha-synuclein by gamma-glutamyl-epsilon-lysine bonds in Alzheimer's neurofibrillary tangles. FASEB J 18:1135-1137

Neumann M, Rademakers R, Roeber S, Baker M, Kretzschmar HA, Mackenzie IR (2009) A new subtype of frontotemporal lobar degeneration with FUS pathology. Brain 132:2922-2931

Oberstadt M, Mitter D, Classen J, Baum P (2016) Late onset dHMN II caused by c.404C $>$ G mutation in HSPB1 gene. J Peripher Nerv Syst 21:111-113

Odgerel Z, Sarkozy A, Lee HS, McKenna C, Rankin J, Straub V, Lochmuller H, Paola F, D'Amico A, Bertini E, Bushby K, Goldfarb LG (2010) Inheritance patterns and phenotypic features of myofibrillar myopathy associated with a BAG3 mutation. Neuromuscul Disord 20:438-442

Ojha J, Karmegam RV, Masilamoni JG, Terry AV, Cashikar AG (2011a) Behavioral defects in chaperone-deficient Alzheimer's disease model mice. PLoS One 6:e16550

Ojha J, Masilamoni G, Dunlap D, Udoff RA, Cashikar AG (2011b) Sequestration of toxic oligomers by HspB1 as a cytoprotective mechanism. Mol Cell Biol 31:3146-3157

Oliveira AO, Osmand A, Outeiro TF, Muchowski PJ, Finkbeiner S (2016) alphaB-Crystallin overexpression in astrocytes modulates the phenotype of the BACHD mouse model of Huntington's disease. Hum Mol Genet 25:1677-1689 
Olzscha H, Schermann SM, Woerner AC, Pinkert S, Hecht MH, Tartaglia GG, Vendruscolo M, Hayer-Hartl M, Hartl FU, Vabulas RM (2011) Amyloid-like aggregates sequester numerous metastable proteins with essential cellular functions. Cell 144:67-78

Outeiro TF, Klucken J, Strathearn KE, Liu F, Nguyen P, Rochet JC, Hyman BT, McLean PJ (2006) Small heat shock proteins protect against alpha-synuclein-induced toxicity and aggregation. Biochem Biophys Res Commun 351:631-638

Patel YJ, Payne Smith MD, de Belleroche J, Latchman DS (2005) Hsp27 and Hsp70 administered in combination have a potent protective effect against FALS-associated SOD1-mutant-induced cell death in mammalian neuronal cells. Brain Res Mol Brain Res 134:256-274

Paulson HL, Shakkottai VG, Clark HB, Orr HT (2017) Polyglutamine spinocerebellar ataxias - from genes to potential treatments. Nat Rev Neurosci 18:613-626

Poewe W, Seppi K, Tanner CM, Halliday GM, Brundin P, Volkmann J, Schrag AE, Lang AE (2017) Parkinson disease. Nat Rev Dis Primers 3:17013

Prabhu S, Raman B, Ramakrishna T, Rao Ch M (2012) HspB2/myotonic dystrophy protein kinase binding protein (MKBP) as a novel molecular chaperone: structural and functional aspects. PLoS One 7: e29810

Qi Z, Shen L, Zhou H, Jiang Y, Lan L, Luo L, Yin Z (2014) Phosphorylation of heat shock protein 27 antagonizes TNF-alpha induced HeLa cell apoptosis via regulating TAK1 ubiquitination and activation of p38 and ERK signaling. Cell Signal 26:1616-1625

Renkawek K, Voorter CE, Bosman GJ, van Workum FP, de Jong WW (1994) Expression of alpha B-crystallin in Alzheimer's disease. Acta Neuropathol 87:155-160

Renton AE, Majounie E, Waite A, Simon-Sanchez J, Rollinson S, Gibbs JR, Schymick JC, Laaksovirta H, van Swieten JC, Myllykangas L, Kalimo H, Paetau A, Abramzon Y, Remes AM, Kaganovich A, Scholz SW, Duckworth J, Ding J, Harmer DW, Hernandez DG et al (2011) A hexanucleotide repeat expansion in C9ORF72 is the cause of chromosome 9p21-linked ALS-FTD. Neuron 72:257-268

Rice HC, de Malmazet D, Schreurs A, Frere S, Van Molle I, Volkov AN, Creemers E, Vertkin I, Nys J, Ranaivoson FM, Comoletti D, Savas JN, Remaut H, Balschun D, Wierda KD, Slutsky I, Farrow K, De Strooper B, de Wit J (2019) Secreted amyloid-beta precursor protein functions as a GABABR1a ligand to modulate synaptic transmission. Science 363(6423):eaao4827

Roan NR, Muller JA, Liu H, Chu S, Arnold F, Sturzel CM, Walther P, Dong M, Witkowska HE, Kirchhoff F, Munch J, Greene WC (2011) Peptides released by physiological cleavage of semen coagulum proteins form amyloids that enhance HIV infection. Cell Host Microbe 10:541-550

Roan NR, Sandi-Monroy N, Kohgadai N, Usmani SM, Hamil KG, Neidleman J, Montano M, Standker L, Rocker A, Cavrois M, Rosen J, Marson K, Smith JF, Pilcher CD, Gagsteiger F, Sakk O, O'Rand M, Lishko PV, Kirchhoff F, Munch J et al. (2017) Semen amyloids participate in spermatozoa selection and clearance. Elife 6: e24888

Robertson AL, Headey SJ, Saunders HM, Ecroyd H, Scanlon MJ, Carver JA, Bottomley SP (2010) Small heat-shock proteins interact with a flanking domain to suppress polyglutamine aggregation. Proc Natl Acad Sci U S A 107:10424-10429

Rosen DR, Siddique T, Patterson D, Figlewicz DA, Sapp P, Hentati A, Donaldson D, Goto J, O'Regan JP, Deng HX et al (1993) Mutations in $\mathrm{Cu} / \mathrm{Zn}$ superoxide dismutase gene are associated with familial amyotrophic lateral sclerosis. Nature 362:59-62

Rossor AM, Kalmar B, Greensmith L, Reilly MM (2012) The distal hereditary motor neuropathies. J Neurol Neurosurg Psychiatry 83: 6-14

Rossor AM, Morrow JM, Polke JM, Murphy SM, Houlden H, Inc R, Laura M, Manji H, Blake J, Reilly MM (2017) Pilot phenotype and natural history study of hereditary neuropathies caused by mutations in the HSPB1 gene. Neuromuscul Disord 27:50-56

Sahara N, Maeda S, Yoshiike Y, Mizoroki T, Yamashita S, Murayama M, Park JM, Saito Y, Murayama S, Takashima A (2007) Molecular chaperone-mediated tau protein metabolism counteracts the formation of granular tau oligomers in human brain. J Neurosci Res 85: 3098-3108

Santhoshkumar P, Sharma KK (2004) Inhibition of amyloid fibrillogenesis and toxicity by a peptide chaperone. Mol Cell Biochem 267:147-155

Selcen D, Muntoni F, Burton BK, Pegoraro E, Sewry C, Bite AV, Engel AG (2009) Mutation in BAG3 causes severe dominant childhood muscular dystrophy. Ann Neurol 65:83-89

Selkoe DJ (2001) Alzheimer's disease: genes, proteins, and therapy. Physiol Rev 81:741-766

Selkoe DJ, Hardy J (2016) The amyloid hypothesis of Alzheimer's disease at 25 years. EMBO Mol Med 8:595-608

Shammas SL, Waudby CA, Wang S, Buell AK, Knowles TP, Ecroyd H, Welland ME, Carver JA, Dobson CM, Meehan S (2011) Binding of the molecular chaperone alphaB-crystallin to Abeta amyloid fibrils inhibits fibril elongation. Biophys J 101:1681-1689

Sharp PS, Akbar MT, Bouri S, Senda A, Joshi K, Chen HJ, Latchman DS, Wells DJ, de Belleroche J (2008) Protective effects of heat shock protein 27 in a model of ALS occur in the early stages of disease progression. Neurobiol Dis 30:42-55

Shatov VM, Weeks SD, Strelkov SV, Gusev NB (2018) The Role of the Arginine in the Conserved N-Terminal Domain RLFDQxFG Motif of Human Small Heat Shock Proteins HspB1, HspB4, HspB5, HspB6, and HspB8. Int J Mol Sci 19(7):E2112

Shemetov AA, Gusev NB (2011) Biochemical characterization of small heat shock protein HspB8 (Hsp22)-Bag3 interaction. Arch Biochem Biophys 513:1-9

Shimura H, Miura-Shimura Y, Kosik KS (2004) Binding of tau to heat shock protein 27 leads to decreased concentration of hyperphosphorylated tau and enhanced cell survival. J Biol Chem 279:17957-17962

Shinohara H, Inaguma Y, Goto S, Inagaki T, Kato K (1993) Alpha B crystallin and HSP28 are enhanced in the cerebral cortex of patients with Alzheimer's disease. J Neurol Sci 119:203-208

Shy M, Rebelo AP, Feely SM, Abreu LA, Tao F, Swenson A, Bacon C, Zuchner S (2018) Mutations in BAG3 cause adult-onset CharcotMarie-Tooth disease. J Neurol Neurosurg Psychiatry 89:313-315

Smith JF, Knowles TP, Dobson CM, Macphee CE, Welland ME (2006) Characterization of the nanoscale properties of individual amyloid fibrils. Proc Natl Acad Sci U S A 103:15806-15811

Soldner F, Stelzer Y, Shivalila CS, Abraham BJ, Latourelle JC, Barrasa MI, Goldmann J, Myers RH, Young RA, Jaenisch R (2016) Parkinson-associated risk variant in distal enhancer of alphasynuclein modulates target gene expression. Nature 533:95-99

Stancanelli C, Fabrizi GM, Ferrarini M, Cavallaro T, Taioli F, Di Leo R, Russo M, Gentile L, Toscano A, Vita G, Mazzeo A (2015) CharcotMarie-Tooth 2F: phenotypic presentation of the Arg136Leu HSP27 mutation in a multigenerational family. Neurol Sci 36:1003-1006

Stengel F, Baldwin AJ, Painter AJ, Jaya N, Basha E, Kay LE, Vierling E, Robinson CV, Benesch JL (2010) Quaternary dynamics and plasticity underlie small heat shock protein chaperone function. Proc Natl Acad Sci U S A 107:2007-2012

Sugiyama Y, Suzuki A, Kishikawa M, Akutsu R, Hirose T, Waye MM, Tsui SK, Yoshida S, Ohno S (2000) Muscle develops a specific form of small heat shock protein complex composed of MKBP/HSPB2 and HSPB3 during myogenic differentiation. J Biol Chem 275: 1095-1104

Tang B, Liu X, Zhao G, Luo W, Xia K, Pan Q, Cai F, Hu Z, Zhang C, Chen B, Zhang F, Shen L, Zhang R, Jiang H (2005) Mutation analysis of the small heat shock protein 27 gene in chinese patients with Charcot-Marie-Tooth disease. Arch Neurol 62:1201-1207 
Tang D, Kang R, Livesey KM, Kroemer G, Billiar TR, Van Houten B, Zeh HJ 3rd, Lotze MT (2011) High-mobility group box 1 is essential for mitochondrial quality control. Cell Metab 13:701-711

Taylor JP, Brown RH Jr, Cleveland DW (2016) Decoding ALS: from genes to mechanism. Nature 539:197-206

Teuchert M, Fischer D, Schwalenstoecker B, Habisch HJ, Bockers TM, Ludolph AC (2006) A dynein mutation attenuates motor neuron degeneration in SOD1(G93A) mice. Exp Neurol 198:271-274

Timmerman V, Raeymaekers P, Nelis E, De Jonghe P, Muylle L, Ceuterick C, Martin JJ, Van Broeckhoven C (1992) Linkage analysis of distal hereditary motor neuropathy type II (distal HMN II) in a single pedigree. J Neurol Sci 109:41-48

Toth ME, Szegedi V, Varga E, Juhasz G, Horvath J, Borbely E, Csibrany B, Alfoldi R, Lenart N, Penke B, Santha M (2013) Overexpression of Hsp27 ameliorates symptoms of Alzheimer's disease in APP/PS1 mice. Cell Stress Chaperones 18:759-771

Trinh J, Farrer M (2013) Advances in the genetics of Parkinson disease. Nat Rev Neurol 9:445-454

Tue NT, Shimaji K, Tanaka N, Yamaguchi M (2012) Effect of alphaBcrystallin on protein aggregation in Drosophila. J Biomed Biotechnol 2012:252049

Turco E, Witt M, Abert C, Bock-Bierbaum T, Su MY, Trapannone R, Sztacho M, Danieli A, Shi X, Zaffagnini G, Gamper A, Schuschnig M, Fracchiolla D, Bernklau D, Romanov J, Hartl M, Hurley JH, Daumke O, Martens S (2019) FIP200 Claw Domain Binding to p62 Promotes Autophagosome Formation at Ubiquitin Condensates. Mol Cell 74(2):330-346.e11

van Es MA, Hardiman O, Chio A, Al-Chalabi A, Pasterkamp RJ, Veldink JH, van den Berg LH (2017) Amyotrophic lateral sclerosis. Lancet 390:2084-2098

Van Montfort R, Slingsby C, Vierling E (2001) Structure and function of the small heat shock protein/alpha-crystallin family of molecular chaperones. Adv Protein Chem 59:105-156

Vatsavayai SC, Nana AL, Yokoyama JS, Seeley WW (2019) C9orf72FTD/ALS pathogenesis: evidence from human neuropathological studies. Acta Neuropathol 137:1-26

Vleminckx V, Van Damme P, Goffin K, Delye H, Van Den Bosch L, Robberecht W (2002) Upregulation of HSP27 in a transgenic model of ALS. J Neuropathol Exp Neurol 61:968-974

Vos MJ, Zijlstra MP, Kanon B, van Waarde-Verhagen MA, Brunt ER, Oosterveld-Hut HM, Carra S, Sibon OC, Kampinga HH (2010) HSPB7 is the most potent polyQ aggregation suppressor within the HSPB family of molecular chaperones. Hum Mol Genet 19: 4677-4693

Wang Y, Mandelkow E (2016) Tau in physiology and pathology. Nat Rev Neurosci 17:5-21

Waudby CA, Knowles TP, Devlin GL, Skepper JN, Ecroyd H, Carver JA, Welland ME, Christodoulou J, Dobson CM, Meehan S (2010) The interaction of alphaB-crystallin with mature alpha-synuclein amyloid fibrils inhibits their elongation. Biophys J 98:843-851

Wilhelmus MM, Boelens WC, Otte-Holler I, Kamps B, de Waal RM, Verbeek MM (2006a) Small heat shock proteins inhibit amyloidbeta protein aggregation and cerebrovascular amyloid-beta protein toxicity. Brain Res 1089:67-78

Wilhelmus MM, Boelens WC, Otte-Holler I, Kamps B, Kusters B, MaatSchieman ML, de Waal RM, Verbeek MM (2006b) Small heat shock protein HspB8: its distribution in Alzheimer's disease brains and its inhibition of amyloid-beta protein aggregation and cerebrovascular amyloid-beta toxicity. Acta Neuropathol 111:139-149

Wood TE, Barry J, Yang Z, Cepeda C, Levine MS, Gray M (2019) Mutant huntingtin reduction in astrocytes slows disease progression in the BACHD conditional Huntington's disease mouse model. Hum Mol Genet 28:487-500

Wurzer B, Zaffagnini G, Fracchiolla D, Turco E, Abert C, Romanov J, Martens S (2015) Oligomerization of p62 allows for selection of ubiquitinated cargo and isolation membrane during selective autophagy. Elife 4:e08941

Wyttenbach A, Sauvageot O, Carmichael J, Diaz-Latoud C, Arrigo AP, Rubinsztein DC (2002) Heat shock protein 27 prevents cellular polyglutamine toxicity and suppresses the increase of reactive oxygen species caused by huntingtin. Hum Mol Genet 11:1137-1151

Yang Z, Klionsky DJ (2010) Mammalian autophagy: core molecular machinery and signaling regulation. Curr Opin Cell Biol 22:124 131

Yerbury JJ, Gower D, Vanags L, Roberts K, Lee JA, Ecroyd H (2013) The small heat shock proteins alphaB-crystallin and Hsp27 suppress SOD1 aggregation in vitro. Cell Stress Chaperones 18:251-257

Ylikallio E, Johari M, Konovalova S, Moilanen JS, Kiuru-Enari S, Auranen M, Pajunen L, Tyynismaa H (2014) Targeted nextgeneration sequencing reveals further genetic heterogeneity in axonal Charcot-Marie-Tooth neuropathy and a mutation in HSPB1. Eur J Hum Genet 22:522-527

Ylikallio E, Konovalova S, Dhungana Y, Hilander T, Junna N, Partanen JV, Toppila JP, Auranen M, Tyynismaa H (2015) Truncated HSPB1 causes axonal neuropathy and impairs tolerance to unfolded protein stress. BBA Clin 3:233-242

Zabel C, Chamrad DC, Priller J, Woodman B, Meyer HE, Bates GP, Klose J (2002) Alterations in the mouse and human proteome caused by Huntington's disease. Mol Cell Proteomics 1:366-375

Zaffagnini G, Savova A, Danieli A, Romanov J, Tremel S, Ebner M, Peterbauer T, Sztacho M, Trapannone R, Tarafder AK, Sachse C, Martens S (2018) p62 filaments capture and present ubiquitinated cargos for autophagy. EMBO J 37(5):e98308

Zhang F, Strom AL, Fukada K, Lee S, Hayward LJ, Zhu H (2007) Interaction between familial amyotrophic lateral sclerosis (ALS)linked SOD1 mutants and the dynein complex. J Biol Chem 282: 16691-16699

Zourlidou A, Payne Smith MD, Latchman DS (2004) HSP27 but not HSP70 has a potent protective effect against alpha-synucleininduced cell death in mammalian neuronal cells. J Neurochem 88: 1439-1448

Zourlidou A, Gidalevitz T, Kristiansen M, Landles C, Woodman B, Wells DJ, Latchman DS, de Belleroche J, Tabrizi SJ, Morimoto RI, Bates GP (2007) Hsp27 overexpression in the R6/2 mouse model of Huntington's disease: chronic neurodegeneration does not induce Hsp27 activation. Hum Mol Genet 16:1078-1090

Publisher's note Springer Nature remains neutral with regard to jurisdictional claims in published maps and institutional affiliations. 